\title{
Późnośredniowieczne czekany, topory i siekiery z pogranicza Małopolski i Rusi Czerwonej w XIV-XV w.
}

\author{
Late Medieval Hammer Axes and Axes \\ from the Border of Lesser Poland and Red Ruthenia \\ in the $14^{\text {th }}$ and $15^{\text {th }}$ Centuries
}

\begin{abstract}
Abstrakt: Obszar obecnego regionu lubelskiego był w średniowieczu pograniczem historycznej Małopolski i Rusi Czerwonej, o które rywalizowali ówcześni władcy Polski, Węgier i Litwy powołujący się na więzy krwi i prawa do dziedziczenia. Rościli pretensje do terytorium Rusi Czerwonej. Konflikty polityczne angażowały przedstawicieli dynastii Rurykowiczów, Arpadów, Andegawenów, Piastów i Gedyminowiczów.
\end{abstract}

Po przyłączeniu Rusi do Korony Polskiej w 1387 r. rozpoczęła się intensywna kolonizacja i latynizacja tych ziem. Skutkiem wspomnianych wydarzeń jest duża liczba znalezisk militariów, w tym czekanów i toporów. Liczne egzemplarze posiadają wybite znaki kowalskie oraz zdobienia. Opisane militaria znajdują się w zbiorach muzeów w Lublinie, Zamościu, Hrubieszowie, Krasnymstawie, Kraśniku i Tomaszowie Lubelskim.

Słowa kluczowe: Małopolska, Ruś Czerwona, Węgry, Litwa, Piastowie, Arpadowie, Andegawenowie, czekany, topory, średniowiecze

Dzisiejsza Lubelszczyzna to obszar pograniczny Małopolski i Rusi Czerwonej, gdzie w epoce średniowiecza ( $\mathrm{XIV}-\mathrm{XV}$ w.) krzyżowały się polityczne interesy władców Polski, Węgier i Litwy, w które sporadycznie wtrącali się krymscy Tatarzy. Sytuację dodatkowo komplikowały spory dynastyczne. Na polsko-węgierskim zjeździe w Wyszehradzie (I339 r.) uzgodniono, że w przypadku śmierci Kazimierza III Wielkiego, jeśliby nie zostawił męskiego potomka, królem Polski zostanie Karol Robert Andegaweński (ożeniony z siostrą Kazimierza, Elżbietą Łokietkówną) lub jego syn. Jeśliby jednak Kazimierz pozostawił dziedzica tronu, to Węgry będą mogły wykupić od niego Ruś. 


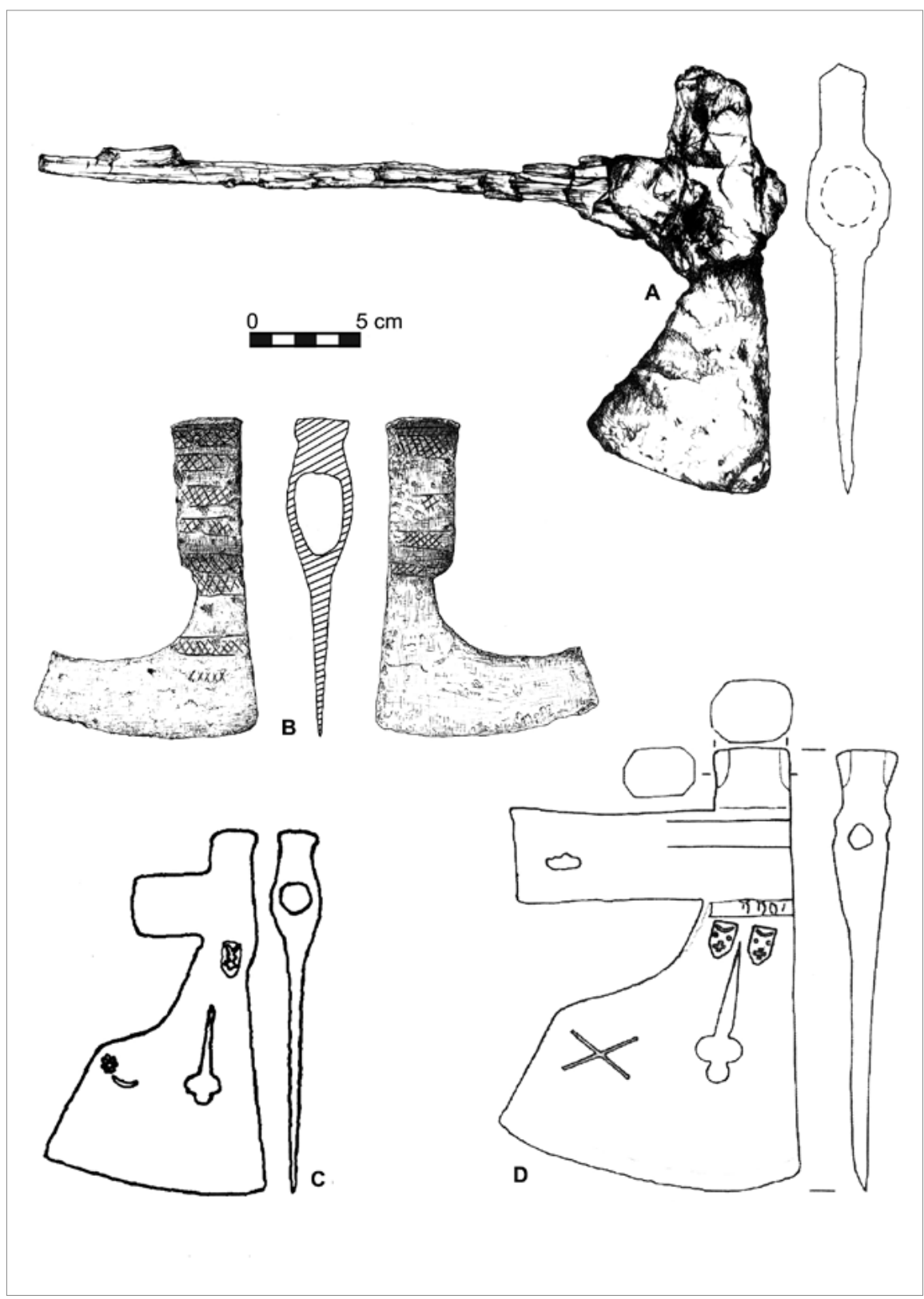

Tabl. ı.Czekany. Typ If: A - Chełm, nr kat. I. Typ ıе: в - Kraśnik, nr kat. 2. Typ Ig: c - Urzędów, nr kat. 4; D - Swaryczów, nr kat. 3. A - wg Bronicki i in. 1991: ryc. I3, b; B - ryc. Archiwum Działu Archeologii Muzeum Narodowego w Lublinie; c - wg Głosek 1996: tabl. vıII, A; D - ryc. J. Kuśnierz. 


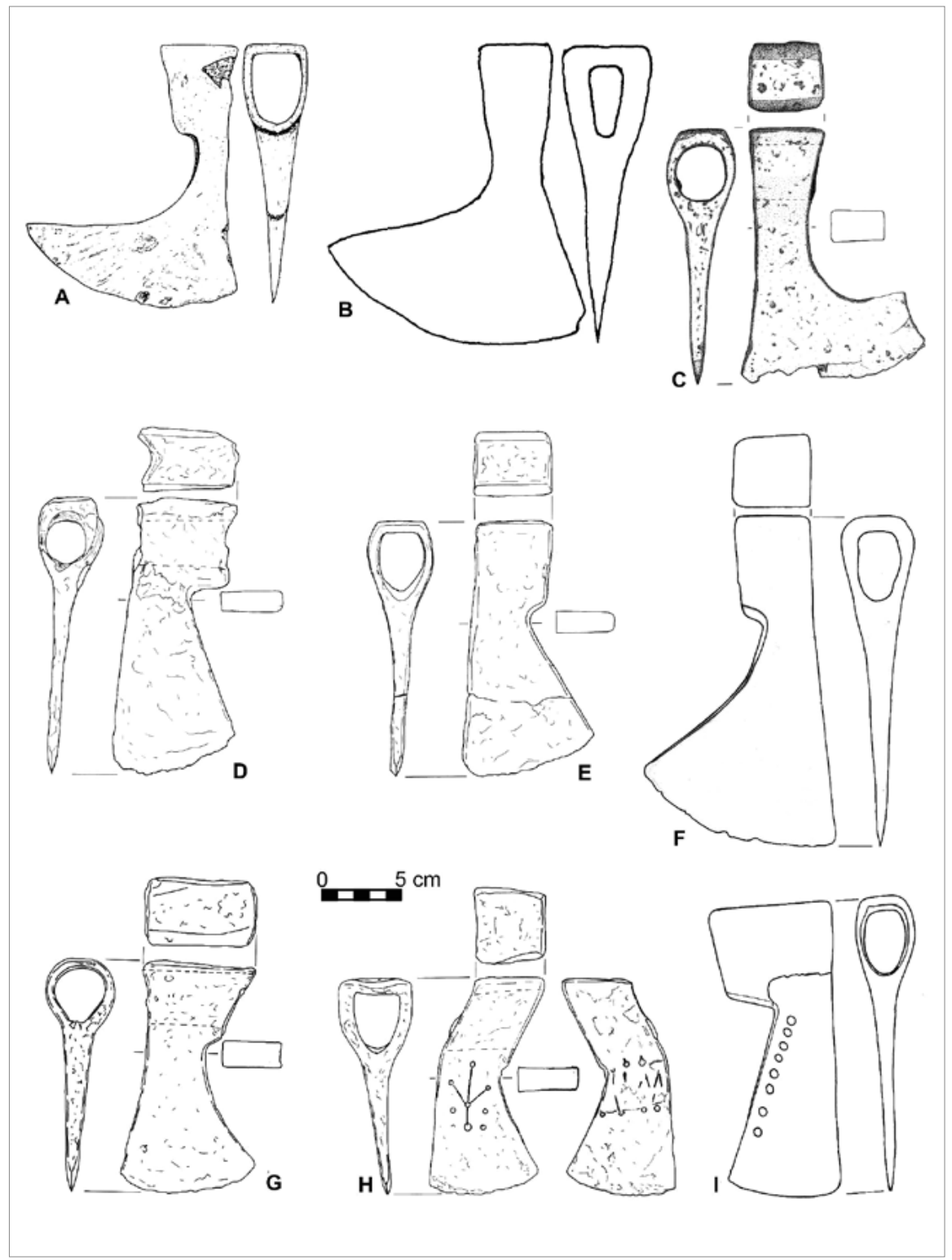

Tabl. II. Topory i siekiery. Typ vd: A - Goraj, nr kat. 4. Typ viI: B - Lublin, nr kat. II. Typ vira: C - Leliszka, nr kat. 8. Typ viII: D - Osuchy, nr kat. I9; E - Osuchy, nr kat. 20; F - m.n., dawne woj. zamojskie, nr kat. 32; G - Leliszka, nr kat. 9; H - Ulów, nr kat. 27; I - m.n. pow. biłgorajski, nr kat. 3I. A - wg Wichrowski 200o: ryc. I; B - wg Głosek 1996: tabl. XII, B; C, D, E, G, H - ryc. P. Kotowicz; F, I - ryc. J. Kuśnierz. 
Księciem halicko-wołyńskim był w tym czasie Bolesław Jerzy II Trojdenowicz, syn Trojdena I z dynastii Piastów mazowieckich i Marii Halickiej, córki księcia Jurija I Lwowicza z dynastii Rurykowiczów. Bolesław Jerzy II był też po kądzieli prawnukiem węgierskiego króla Beli IV z dynastii Arpadów. Sam ożenił się z Eufemią, córką wielkiego księcia litewskiego Gedymina, a siostrą Aldony Gedyminówny, pierwszej żony Kazimierza Wielkiego (zmarła w I339 r.) i tym samym został szwagrem króla. W obliczu zdecydowanej opozycji bojarów Bolesław Jerzy II, chcąc zapewnić sobie poparcie Kazimierza III Wielkiego, przyrzekł mu następstwo na Rusi po swojej śmierci. W kwietniu I340 r. Bolesław Jerzy II został przez bojarów otruty we Włodzimierzu Wołyńskim i o spadek po nim upomnieli się wszyscy sąsiedzi powołujący się na związki rodzinne i prawa do dziedziczenia. Wołyńską część księstwa halicko-włodzimierskiego zają̨ litewski książę Lubart, zaś w części halickiej pojawiły się oddziały polskie i węgierskie. Przeciwko nim bojarzy sprowadzili na pomoc Tatarów. W początkach I34I r. tatarscy interwenci doszli do Lublina, lecz zostali odparci. W tej skomplikowanej sytuacji politycznej książę Lubart w 1344 r. opanował Ruś halicko-włodzimierską. W I349 r. na sporne terytoria wkroczyły wojska Kazimierza III, zajmując Ruś oprócz Łucka, który zatrzymał Lubart, uznając jednak zwierzchnictwo Polski. W I350 r. Giedyminowicze zorganizowali kolejną wyprawę i znowu opanowali Wołyń. W I352 r. na pomoc Kazimierzowi przybyli Węgrzy - doszło m.in. do oblężenia Bełza zajętego przez Litwinów dowodzonych przez Jerzego Narymuntowicza. Podczas tych walk król Węgier Ludwik, syn Karola Roberta Andegaweńskiego, a siostrzeniec Kazimierza, został ranny (Świeżawski 1990: 67 i n.; Voytovych 2011: 37). Bezskuteczne oblężenie Bełza skończyło się jedynie zhołdowaniem litewskiego garnizonu, który symbolicznie wywiesił węgierska flagę. Po okresie intensywnych walk w I352 r. okolice Lwowa na Rusi Czerwonej przypadły królowi polskiemu (choć formalnie nie zostały wcielone do Korony), Litwa zatrzymała Wołyń.

Interesujący nas obszar Kazimierz Wielki zajął podczas wyprawy w I366 r. Ziemie chełmska i bełska Rusi Czerwonej stały się lennem Polski pod rządami litewskiego księcia Jerzego Narymuntowicza. Po śmierci króla Kazimierza (I370 r.) władcą Polski został Ludwik Węgierski (Andegaweński), który w 1372 r., dokumentem wystawionym w Bratysławie (węg. Pozsony), powierzył zarząd Rusi piastowskiemu księciu Władysławowi IV Opolczykowi, prawnukowi Władysława Łokietka. Opolczyk, jako krewny króla Ludwika, piastował też najwyższe urzędy w Królestwie Węgierskim (Świeżawski 2007: 253). Ludwik w trakcie wyprawy wojennej w 1377 r. zajął Bełz, Chełm i Horodło, obsadzając zamki swoimi starostami, poddając ich pod władzę Władysława Opolczyka. Ruś Czerwona została potraktowana jako przynależna Węgrom. Broniący się w Bełzie litewski garnizon pod wodzą Jerzego Narymuntowicza skapitulował, zaś sam książę wraz z żoną i synami dostał się do niewoli węgierskiej (Wyrozumski 1999: 322-328; 
Świeżawski 2007: 258 i n.). Według podań i utrwalonej tradycji Władysławowi Opolczykowi zawdzięczamy wywiezienie z Bełza ikony Matki Bożej obecnie znanej jako M.B. Częstochowska. Opozycja możnowładców, przeciwna związkom z Węgrami i szczególnie wroga w stosunku do księcia Władysława Opolczyka, wysuwała propozycję osadzenia na polskim tronie księcia mazowieckiego (Piasta) Siemowita IV (Manteuffel, Dowiat 1980: 98). Po śmierci Ludwika Węgierskiego (1382 r.) nastąpiła eskalacja sporów między wrogimi stronnictwami. Po dwóch latach bezkrólewia (1382-1384) i konfliktów między zwolennikami Siemowita IV a możnowładcami małopolskimi popierającymi Jadwigę Andegaweńską (córkę Ludwika), uzgodniono podstawowy warunek stałego pobytu Jadwigi w Polsce i w październiku i384 r. koronowano ją na „króla Polski” (Manteuffel, Dowiat 1980: 98 n.). Uznano też, że odzyskaniu Rusi i zakończeniu napadów litewskich sprzyjać będzie małżeństwo Jadwigi z wielkim księciem litewskim Jagiełłą. Aktem unii zawartej w Krewie ( 1385 r.) Jagiełło zaakceptował stawiane przez Polaków warunki małżeństwa i uzyskania godności królewskiej, a 2 lutego 1386 r. zjazd szlachty w Lublinie dokonał formalnej elekcji (Szczygieł 2017: 54). Is lutego I386 r. Jagiełło przyjął w Krakowie chrzest pod imieniem Władysław, poślubił Jadwigę i 4 marca został koronowany (Manteuffel, Dowiat 1980: 100; Trawkowski 1980: 106). W 1387 r. Jadwiga zorganizowała wyprawę polskiego rycerstwa na Ruś i odebrała tę prowincję z rąk swoich węgierskich rodaków (Świeżawski 2007: 289). By zaspokoić roszczenia do tronu polskiego zgłaszane przez mazowieckiego Piasta Siemowita IV, Władysław wydał za niego swoją siostrę Aleksandrę i nadał mu w 1388 r. namiestnictwo Rusi, w tym Bełz, Horodło, Lubaczów, Busk, Grabowiec (Janeczek 1993: 32 n.; Szczygieł 2006: 88 n.). Siemowit IV rozpoczął intensywną akcję kolonizacyjną, sprowadzając i osadzając masy niezamożnej szlachty, głównie mazowieckiej (Janeczek 1993: 89-92, mapa 9). Zorganizowana została sieć katolickiej administracji kościelnej, a w rękach osadników znalazła się większość ziemi. Nastąpił czas sprzyjający rozwojowi miast. W 1394 r. obok grodu Szczekarzew powstało miasto Krasnystaw, 29 września I 400 r. we Lwowie został wydany akt lokacji na prawie niemieckim dla Hrubieszowa (Szczygieł 2006: 87, 90). Szczególnie uprzywilejowany był Lublin, w którym król Kazimierz Wielki spotykał się ze swoim siostrzeńcem Ludwikiem Węgierskim. Miasto było bazą wypadową na ziemie ruskie, tu prowadzono rokowania z Litwinami w I358 $\mathrm{r}$. Lublin, ulokowany na trasie częstych podróży króla Jagiełły z Krakowa na rodzinną Litwę, gościł go co najmniej 35 razy. Lublin znalazł się na drodze łączącej dwa stołeczne miasta - Kraków i Wilno (Samsonowicz 1973: 704-704, mapa 3). Podczas licznych objazdów głównych ośrodków królestwa Jagiełło odwiedzał również Chełm, Hrubieszów, Bełz (Baczkowski 1999: 118-119; Tkaczyk 2016: 32-34). W regionie nastąpiła intensyfikacja osadnictwa różnej etnicznie ludności Rzeczypospolitej Obojga Narodów i przybyszów z innych krajów Europy, co przyczyniło się do rozwoju handlu 


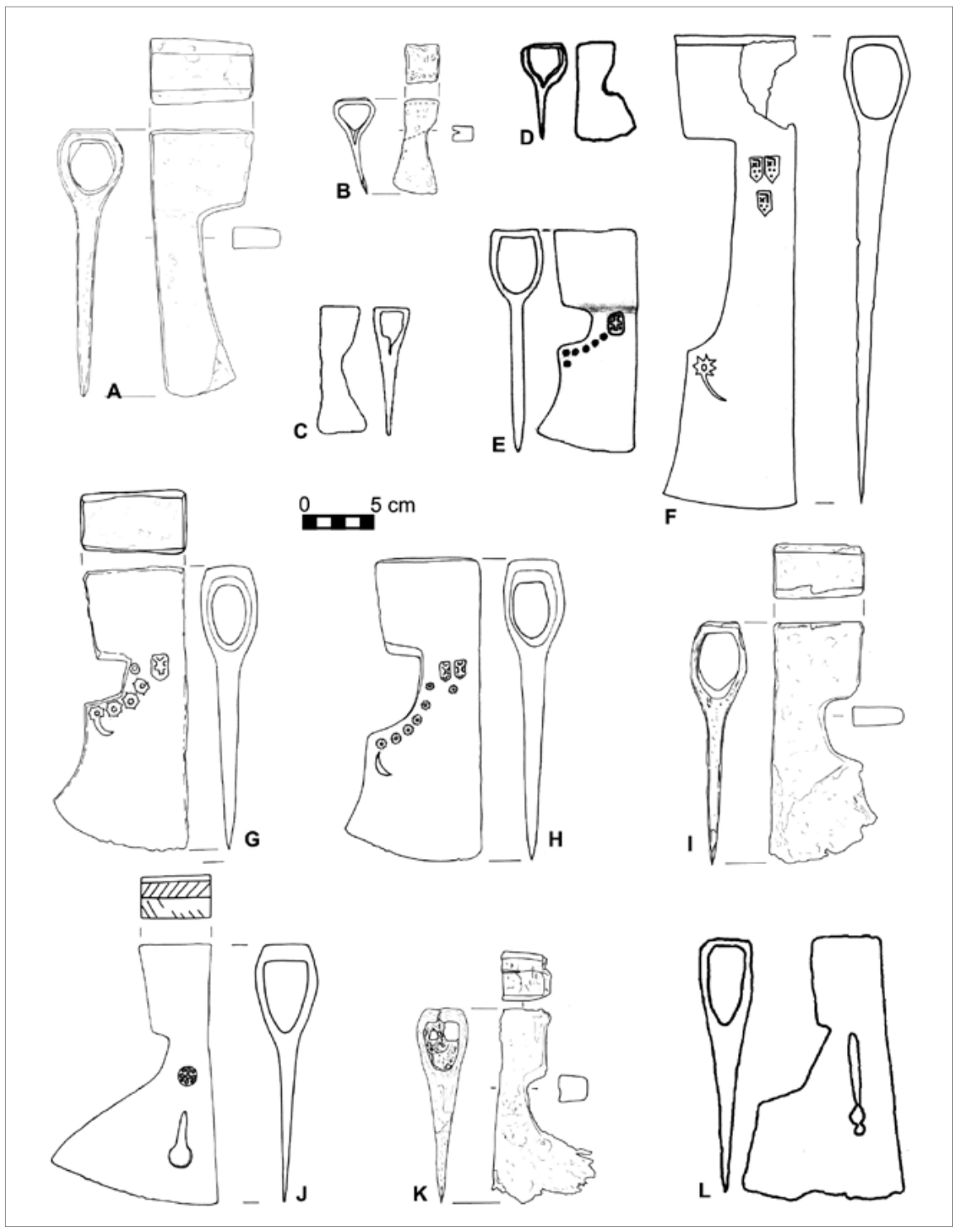

Tabl. III. Topory i siekiery. Typ viII: A - Osuchy, nr kat. 2I; в - Ulów, nr kat. 28; C - „Puszcza Solska”, nr kat. 30. Typ viıra: D - Horodysko, nr kat. 5; E - Łabunie, nr kat. I7; F - Lublin, nr kat. I2; G - Osuchy, nr kat. 22; H - Zanie, nr kat. 29; I - Kolonia Rogóźno, nr kat. 7. Typ IX: J - Lublin, nr kat. I3; K - Osuchy, nr kat. 23. Typ Ixa: L - Sąsiadka, nr kat. 26.

A, B, G, I, K - ryc. P. Kotowicz; C - wg Ławrynowicz, Strzyż 20oI: ryc. 2:6;

D, L - wg Głosek 1996: tabl. XV, B i XXIII, B; E, H - ryc. J. Kuśnierz; F, J - Archiwum Działu Archeologii Muzeum Narodowego w Lublinie. 


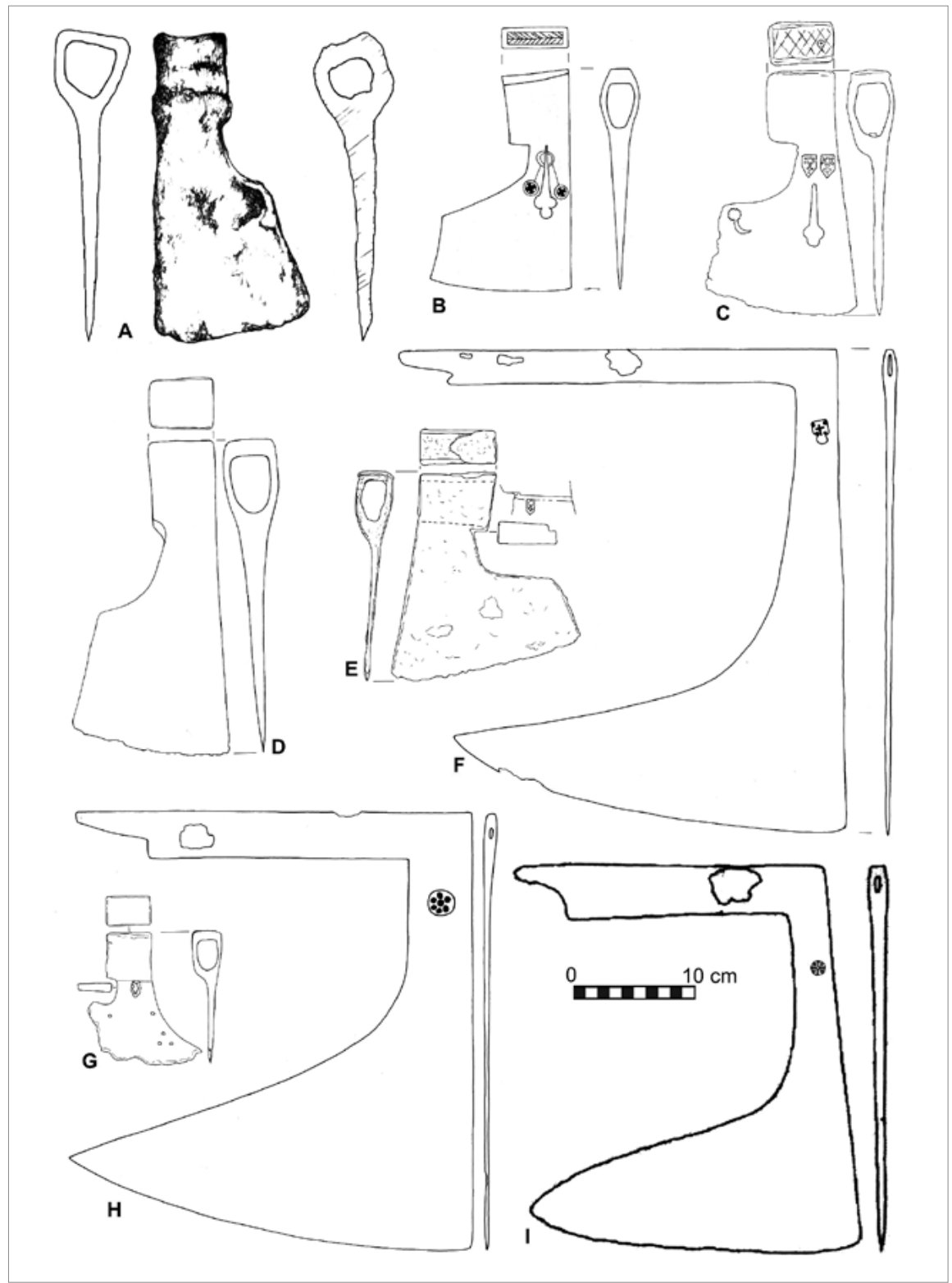

Tabl. IV. Topory i siekiery. Typ IXa: A - Chełm, nr kat. 2; B - Lublin, nr kat. I4;

C - Orłów Murowany, nr kat. 18; D - Czechów Kąt, nr kat. 3; E - Paary, nr kat. 24;

F - Lublin, nr kat. I5; G - Perespa, nr kat. 25. Typ x: H - Lublin, nr kat. I6;

I - Hrubieszów, nr kat. 6.

A - wg Bronicki i in. 1991: ryc. I3, a; B, F, H - Archiwum Działu Archeologii Muzeum Narodowego w Lublinie; C, D, I - ryc. J. Kuśnierz; E, G - ryc. P. Kotowicz. 
i rzemiosła. W XV w. naliczono w Lublinie 4I różnych specjalności rzemieślniczych (Szczygieł 2017: 55 n.). Po okresie pewnej stabilizacji nastąpił wybuch wojny krzyżacko-polskiej. Lektura kronik Jana Długosza przynosi informacje o chorągwiach rycerskich wystawionych przez poszczególne ziemie. I tak z ziem Małopolski przyległych do Rusi Czerwonej na miejscu bitwy pod Grunwaldem stanęly chorągwie ziemi sandomierskiej i ziemi lubelskiej. Ruś Czerwona wystawiła chorągiew ziemi lwowskiej, ziemi przemyskiej i ziemi chełmskiej. Szczególnie interesująca dla niniejszych rozważań jest chorągiew „gończa”, z pięcioma rycerzami na czele, wśród których znalazł się Jan Sarunik z Nabroża (ziemia bełska), który przez 16 lat służył jako wódz u sułtana tureckiego (Jan Długosz: 102-104). Wrócił on z wojny do rodzinnej posiadłości i w I4II r. ufundował w niej kościół (Zahajkiewicz 1985: 351 - tu jako „Jan Szompnik”).

Wspomniane wyżej wydarzenia polityczne w XIV i XV w. oraz związane z nimi przemarsze licznych wojsk miały zapewne znaczący wpływ na dużą liczbę znalezisk broni, w tym czekanów i toporów. Odkrywane są one na przeprawach rzecznych, w błotnistych dolinach cieków i wzdłuż ważniejszych szlaków komunikacyjnych wiodących zazwyczaj brzegami ważniejszych rzek lub przez dogodne przejścia przez większe kompleksy leśne i pasma wzgórz (Puszcza Sandomierska, Puszcza Solska, Roztocze). Drogami tymi przemieszczały się oddziały wojskowe, karawany kupieckie i liczni podróżni, narażeni często w warunkach odległych gęstwin leśnych na napady rabunkowe. Znane są liczne przykłady wysyłania przez mieszczan wozów z zaopatrzeniem dla wojska poruszających się w otoczeniu eskort zbrojnych uzbrojonych m.in. w topory i siekiery (Szymczak 2016: 290, 29I).

Zapewne równie ważne znaczenie wyrażające się w liczbie odkrywanych obecnie toporów miała tzw. kolonizacja mazowiecka zainicjowana (jak już wspomniano powyżej) przez księcia Siemowita IV. Wiązała się ona z nasiloną eksploatacją lasów i ich karczowaniem przez nowych osadników ${ }^{1}$. Szczególnie dotyczy to zalesionego pasma wzgórz Roztocza i otaczających terenów (Puszczy Solskiej i Lasów Janowskich), których większa część weszła pod koniec XVI w. w skład Ordynacji Zamojskiej. Rozpoczęła się wówczas intensywna akcja osadnicza, wymagająca karczowania lasów pod nowo zakładane osady, młyny, tartaki, kuźnie, huty, browary. Skutkiem była nadmierna eksploatacja lasów dla miejscowych potrzeb. Trzebież zasobów drewna przybrała taką skalę, że w latach 1566 i I57 I na tereny starostwa lubaczowskiego i zamechskiego zjechały komisje królewskie, które po lustracji wydały zakaz „niszczenia lasów” (Szczygieł I994: 8). Opisanej sytuacji historycznej zawdzięczamy zapewne znaczną liczbę rozproszonych znalezisk

1 Mieszczanie z lokowanego w $1375 \mathrm{r}$. Lubaczowa w ziemi bełskiej otrzymali dla swoich łanów wyrąbanych w lesie 16 lat wolnizny od podatków (Świeżawski 2007: 264 n.). 
żeleźców toporów typu viII ${ }^{2}$ (nry kat. 27, 28, 30, 3I), typu viIIa (nry kat. 7, 29) i IXa (nry kat. 24, 26). Osobne zagadnienie stanowi problem określenia charakteru znalezisk toporów na śródleśnej, bagnistej łące (o miejscowej nazwie „Byki”), którą przecina rzeczka Studzianka, niewielki prawy dopływ rzeki Tanwi. Pochodzą stamtąd trzy egzemplarze typu viII (nry kat. 19, 20, 2I) i po jednym okazie typu VIIIa (nr kat. 22) i IX (nr kat. 23). Podmokły teren raczej nie nadaje się do składowania i obróbki pni drzew, rzeczka jest zbyt mała i nie mogła służyć do spławiania urobku. Ponieważ z opisywanej łąki pochodzą dodatkowo dwa egzemplarze starszych toporów datowanych na IX - pierwszą połowę X w. oraz drugą połowę X(?) - XII w. (Kotowicz 20I4: 78, nry kat. 279 i 280) można postawić tezę, że w ciągu kilku wieków miejsce to służyło jako przeprawa na szlaku komunikacyjnym Lwów-Niemirów-Lubaczów-Cieszanów-Zamch-Szczebrzeszyn-Lublin (Szczygieł 1994: mapa nr I). Na odcinku tego szlaku, nieopodal opisywanej Łąki Byki (w odległości o,5 km na południe), leży wieś Borowiec, z którą wiąże się znalezisko ciężkiego, zdobionego topora typu XII (nr kat. I). Oba punkty łączy tzw. Borowiecka Droga biegnąca w kierunku Józefowa-Szczebrzeszyna. Wszystkie opisane wyżej egzemplarze toporów i siekier zlokalizowane zostały w granicach byłej Ordynacji Zamojskiej.

Rzadkimi rodzajami broni obuchowej, znajdowanej na opisywanym terenie, są czekany. Na interesującym nas obszarze odkryto żeleźca czterech egzemplarzy (tabl. I) reprezentujących typy Ie, If i Ig według klasyfikacji M. Głoska (1996: tabl. IV).

Bogato zdobiony czekan typu Ie pochodzi z Kraśnika (tabl. I, B; nr kat. 2). M. Głosek wymienia pięć analogicznych egzemplarzy z terenu Polski, z czego trzy znaleziono na Śląsku, jeden na Pomorzu Wschodnim, zaś jeden, pochodzący z miejscowości nieznanej, przechowywany jest w Muzeum Wojska Polskiego (Głosek 1996: 28-29). Okaz z Kraśnika posiada jeszcze jedną analogię, najbliższą geograficznie. Jest to czekan z miejscowości nieznanej w województwie podlaskim, znajdujący się w zbiorach Muzeum Wojska w Białymstoku (Maciukiewicz-Czarnecka 1992: 112, nr kat. 17, ryc. 17).

Czekan typu If został wydobyty podczas badań archeologicznych ze studni miejskiej na rynku w Chełmie (tabl. I, A, nr kat. I). Egzemplarz z Chełma, omówiony w opracowaniu M. Głoska (1996: 29, nr kat. I), posiada tylko analogie w zbiorach wrocławskich. Jeden z nich to okaz z miejscowości nieznanej, przechowywany w zbiorach Muzeum Narodowego we Wrocławiu (Głosek 1996: 29, tabl.vi, C, nr kat. 17). Drugi egzemplarz to czekan odkryty podczas archeologicznych badań fosy miejskiej na placu Dominikańskim we Wrocławiu (Marek 2008: 137, ryc. 180a).

2 Przy określaniu typologicznym broni obuchowej posługujemy się klasyfikacją M. Głoska (1996). 


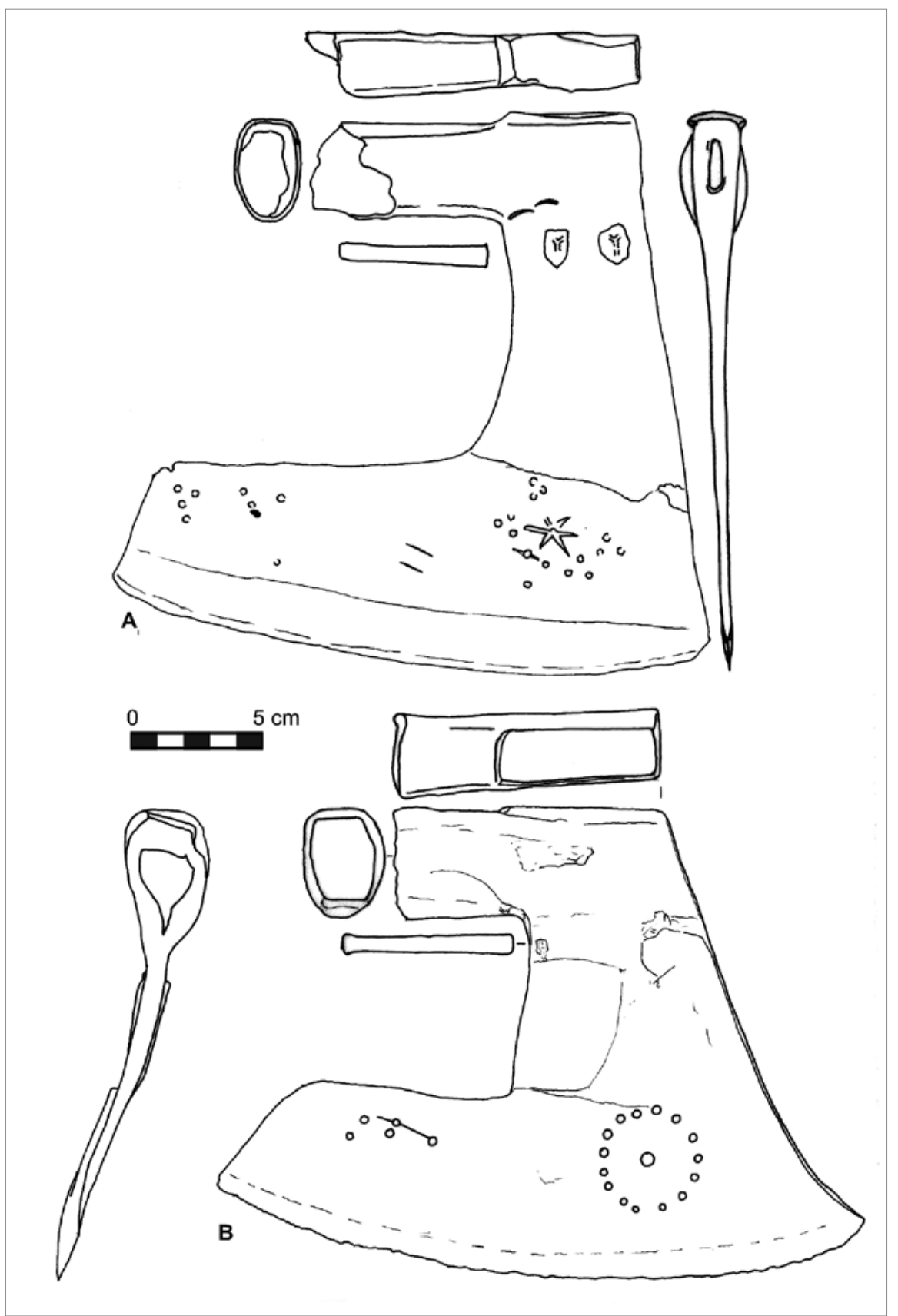

Tabl. v. Topory. Typ xıI: A - Leliszka, nr kat. Iо; B - Borowiec, nr kat. I. A, B - ryc. P. Kotowicz. 
Czekany tego typu nawiązują do egzemplarzy znajdowanych na terenie Czech i datowanych na XIV - początek XV w. oraz do znalezisk węgierskich łączonych z XVI-XVII w. (Głosek 1996: 29-30).

Czekany typu Ig wystąpiły na terenie Lubelszczyzny w dwóch egzemplarzach. Pierwszy z nich, opublikowany przez M. Głoska (1996: 30-31, nr kat. I2, tabl.viII, A), pochodzi z Urzędowa w powiecie kraśnickim (tabl. I, C; nr kat. 4), drugi natomiast ze Swaryczowa w powiecie zamojskim (tabl. I, D; nr kat.3). Takie czekany w Czechach uważane są za uzbrojenie husytów z pierwszej połowy XV w., zaś na Węgrzech datowane są szeroko - od XIV do XVI-XVII w. (Głosek 1996: 30-3I). Niemal idealnym odpowiednikiem okazu ze Swaryczowa, pod względem ogólnego kształtu, zdwojonego znaku kowalskiego i ornamentu na brodzie, jest czekan z nieodległego Radymna (Głosek 1996: 83, nr kat. 6, tabl.vII, E), znaleziony wśród licznych egzemplarzy broni w miejscu dawnej przeprawy przez rzekę San. Przeprawa ta, położona na szlaku prowadzącym z Węgier ku Bełzowi i Włodzimierzowi, funkcjonowała przez kilka stuleci. Na terenie d. Rusi Czerwonej, we Lwowie odległym od Swaryczowa o około $120 \mathrm{~km}$ na południe, znaleziono analogiczny czekan. Zalegał w studni wśród innych przedmiotów datujących ten egzemplarz na XV-XVI w. (Shnicar 2019). Warto tu odnieść się do pojawiających się opinii znawców broni obuchowej stwierdzających, że asymetryczność ostrza (jak w przypadku egzemplarza ze Swaryczowa i Lwowa) pozwala je kwalifikować do kategorii narzędzi ciesielskich. Naszym zdaniem rozbudowana ornamentyka, a przede wszystkim obecność inkrustacji z metalu kolorowego na czekanie ze Swaryczowa, świadczą o jego funkcji bojowej. Asymetryczność ostrza wskazywać może na praworęczności dawnego właściciela-wojownika. Naostrzone, asymetryczne ostrze jest skuteczniejsze w boju, gdyż zapobiega rykoszetowaniu. Natomiast w trakcie szybkiej walki raczej brak jest czasu na ciosy „na odlew" - uderzających od strony lewej.

W tym miejscu trzeba odnieść się do wagi poszczególnych egzemplarzy toporów i siekier. Wydaje się, że jest to jeden z najważniejszych parametrów decydujących o podstawowej funkcji tych przedmiotów. Na ten aspekt zwrócił już uwagę A.N. Kirpichnikov, wydzielając kategorię czekanów i toporów bojowych ważących do 450 g oraz siekier o wadze 600-800 g (Kirpichnikov 1966: 28, tab. 10). Temat podjął w Polsce P. Świątkiewicz, podejmując próbę funkcjonalnego podziału toporów pozyskanych w trakcie badań archeologicznych grodziska w Raciążu, kwalifikując trzy egzemplarze (spośród ogólnej liczby trzynastu okazów lub ich fragmentów) o wadze zamykającej się między 579-600 g jako topory zarówno gospodarcze, jak i bojowe (Świątkiewicz 2010: 28-29).

Analizując wagę egzemplarzy uwzględnionych w niniejszej pracy, otrzymujemy następujący, poniżej opisany wynik. Z ogólnej liczby 32 opisanych w poniższym katalogu toporów i siekier znamy wagę 20 egzemplarzy: 


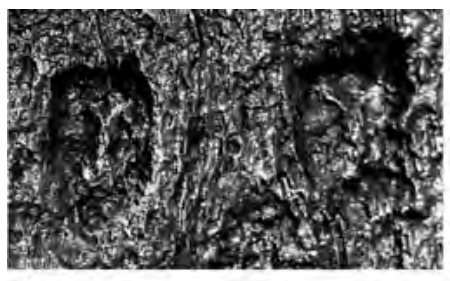

A
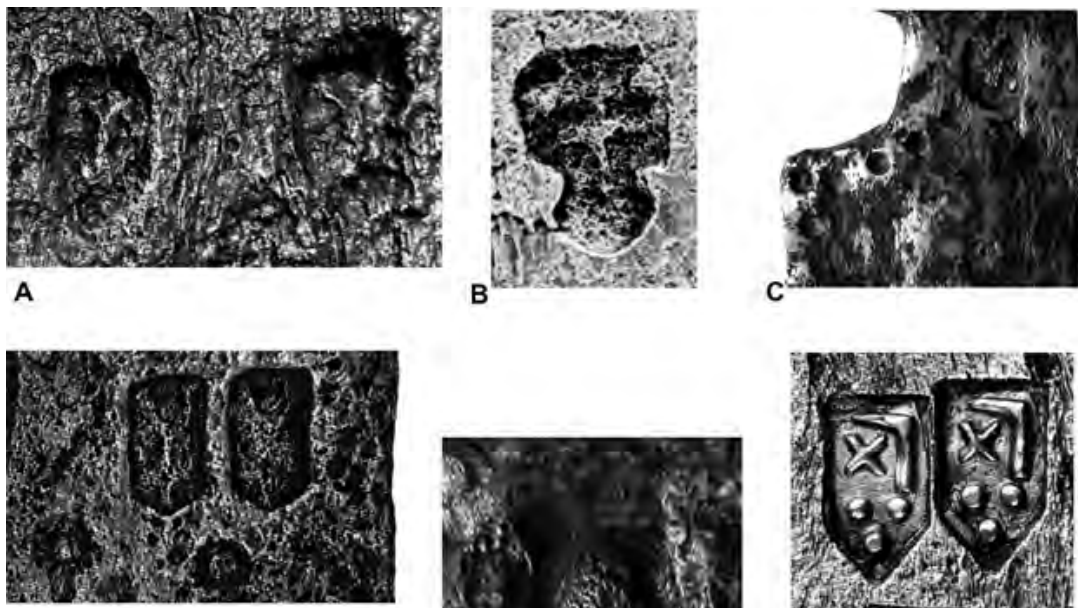

D
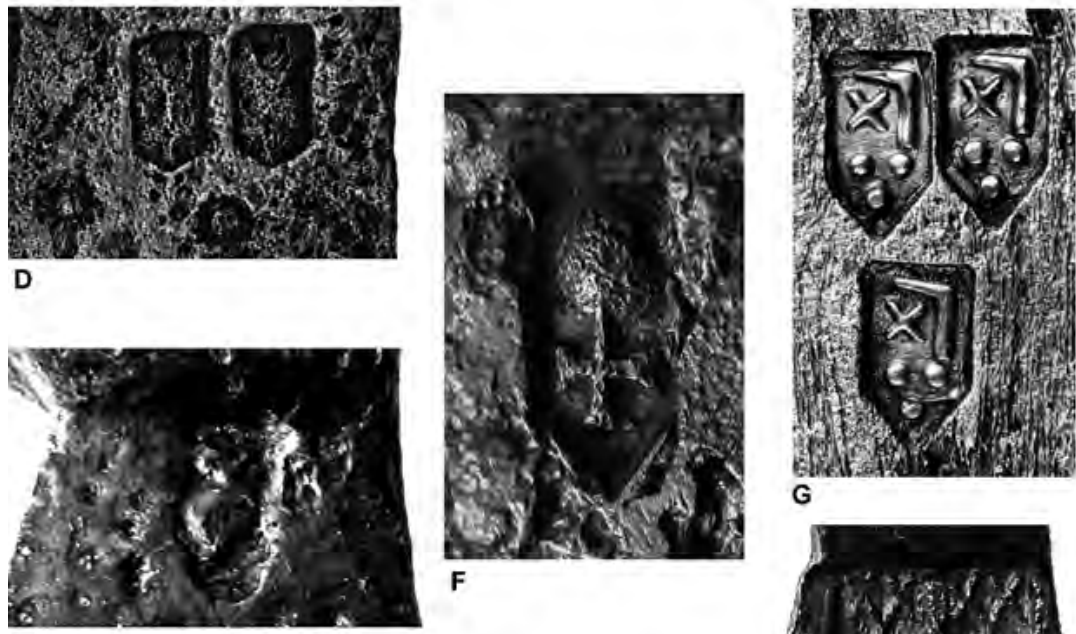

G
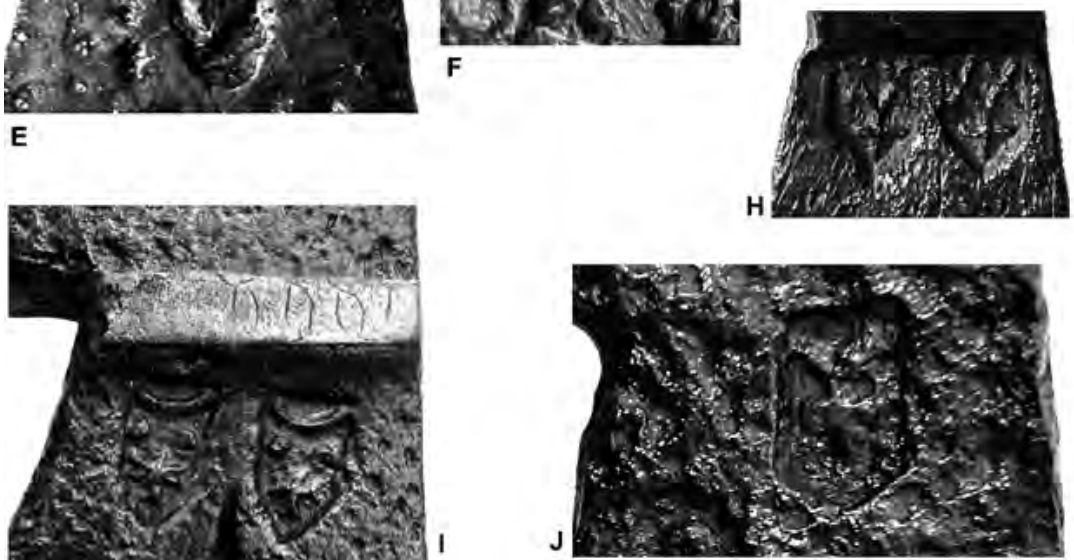

Tabı. Vı. Znaki kowalskie: A - Leliszka, nr kat. IO; B - Lublin, nr kat. I5; C - Łabunie, nr kat. I7; D - Zanie, nr kat. 29; E - Perespa, nr kat. 25; F - Paary, nr kat. 24; G - Lublin, nr kat. I2; H - Orłów Murowany, nr kat. I8; I - Swaryczów, nr kat. czekanów nr 3; J - Osuchy, nr kat. 22.

A, C, E, H, I - fot. J. Kuśnierz; B, G - fot. P. Maciuk; D, J - fot. K. Grochecki. 


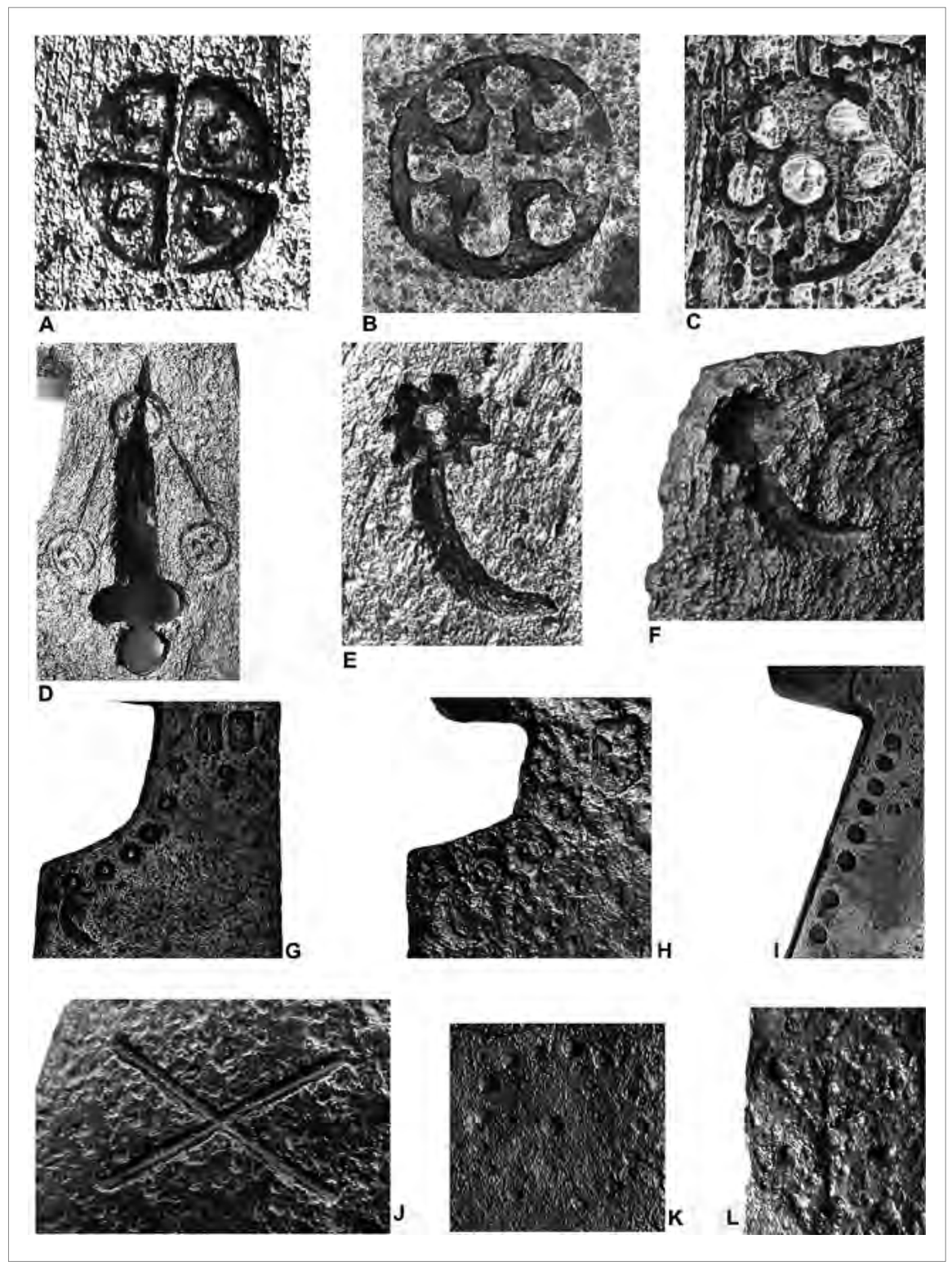

Tabl. VII. Znaki kowalskie i zdobienia: A - Hrubieszów, nr kat. 6; B - Lublin, nr kat. I3; C - Lublin, nr kat. I6; D - Lublin, nr kat. I4; E - Lublin, nr kat. I2; F - Orłów Murowany, nr kat. I8; G - Zanie, nr kat. 29; H - Osuchy, nr kat. 22; I - m.n. pow. biłgorajski, nr kat. 3I; J - Swaryczów, nr kat. czekanów 3; $\mathrm{K}$ - Borowiec, nr kat. I; L - Ulów, nr kat. 27.

F, J, K, L - fot. J. Kuśnierz; A, B, C, D, E - fot. P. Maciuk; G, H, I - fot. K. Grochecki. 


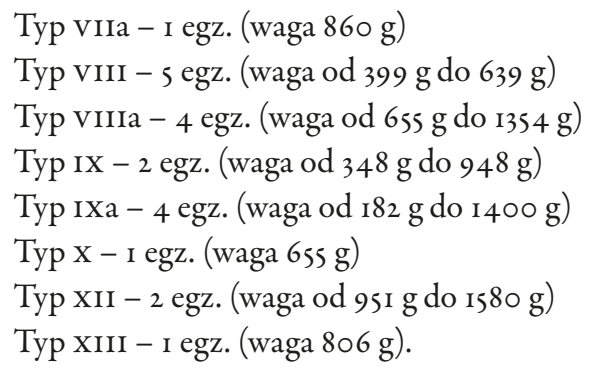

Jeśli chodzi o ogólną statystykę toporów, najwięcej okazów reprezentuje typ viII ( 9 egz.), typ viIIa (6 egz.), typ Ix (6 egz.), rzadziej występuje typ x ( 3 egz.) i typ XII (2 egz.). Szczególna koncentracja znalezisk toporów wystąpiła w dolinie rzeki Tanew ( 9 egz.) i w dolinie rzeki Sołokija płynącej od północy w kierunku Bełza. Najprawdopodobniej znaleziskiem gromadnym jest kolekcja toporów (s egz.) odkrytych, według relacji zastrzegającego sobie anonimowość znalazcy i darczyńcy, u podnóża zamku lubelskiego, w okolicy wiaduktu łączącego dzisiaj wzgórze zamkowe ze starym miastem (nry kat. 12-16). Trudno powiedzieć cokolwiek więcej na temat tej kolekcji, co najwyżej można próbować ją wiązać ze wspomnianym wyżej wzrostem znaczenia miasta i rozwojem miejscowego rzemiosła.

Wśród żeleźców toporów i siekier znalezionych na Lubelszczyźnie znalazły się również egzemplarze miniaturowe o długości mieszczącej się między $6,3-8,0 \mathrm{~cm}$. Dwa toporki (tabl. III, B, C) reprezentujące typ viII znaleziono w lasach d. Ordynacji Zamojskiej. Trudno je wiązać z narzędziami używanymi w ciężkich pracach przy obróbce drewna. Trzeci toporek należy zaliczyć do typu viıIa (tabl.III, D). Znaleziony został podczas badań archeologicznych na grodzisku. Wypowiadając się krótko na temat toporków o zmniejszonych rozmiarach, T. Łaszkiewicz i A. Michalak skłaniają się do sugestii S. Kurnatowskiego, że używane były jako wyspecjalizowane narzędzia (Łaszkiewicz, Michalak 2007: I17). Opinię tę można odnieść również do nieco większego toporka typu Ix (tabl.IV, G), który od poprzednich odróżnia wybity na szyjce znak kowalski.

Tu warto podkreślić fakt bardzo częstego występowania na omawianych zabytkach znaków kowalskich i rozbudowanych ornamentów. W rozpatrywanym zbiorze 36 egzemplarzy broni obuchowej Is posiada znaki kowalskie. Aż dziesięć $\mathrm{z}$ nich to znaki zamknięte w obrysach tarczy herbowej zawierającej różne odmiany krzyży uzupełnionych o kropki, półksiężyce, znaki „x” (tabl. I, C, D; tabl.III, E, F, G, H; tabl. IV, C, E, G; tabl.v, A; tabl.vI). Znaki w postaci tarcz herbowych występują pojedynczo, podwójnie, a w jednym przypadku (tabl. III, F; tabl.vi, G) znak został wybity trzykrotnie, tworząc układ trójkąta. Ten ostatni wart jest szczególnej uwagi, gdyż został pokryty metalem kolorowym. Spośród znaków zamkniętych w obrębie tarczy herbowej zwraca uwagę precyzyjnie wybite przedstawienie 


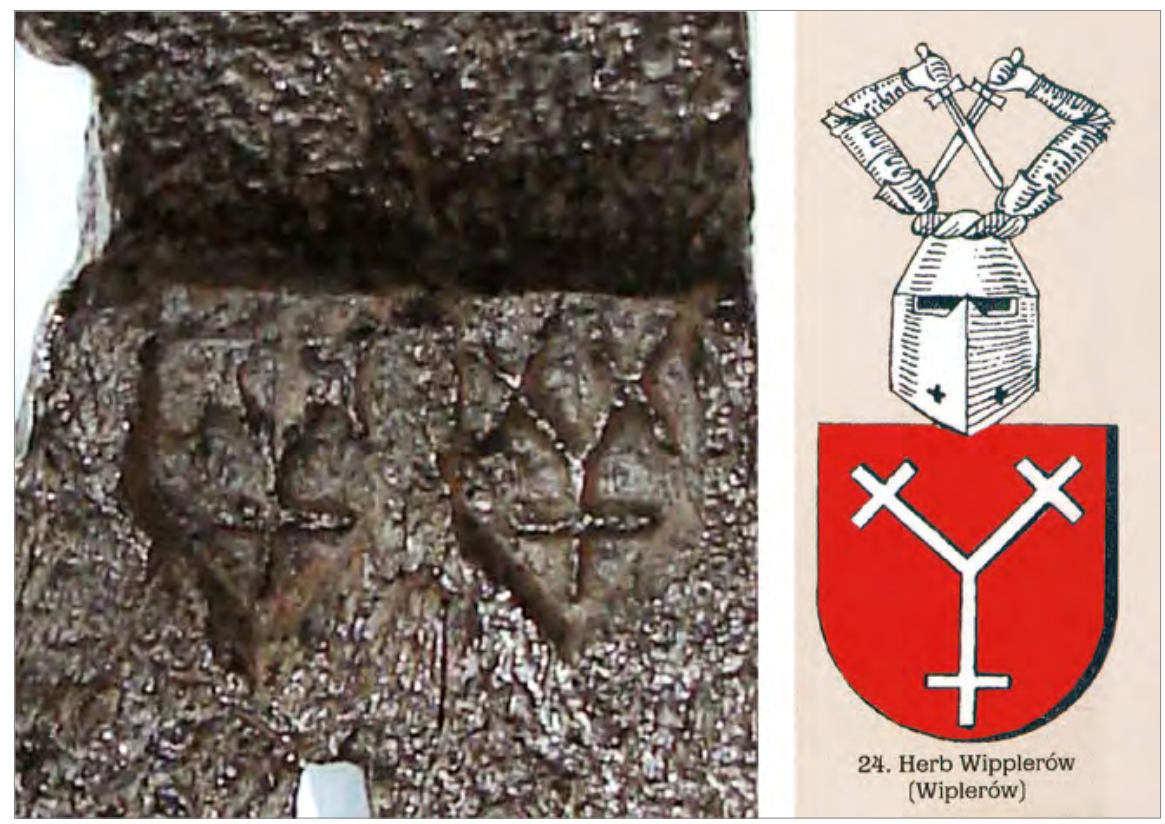

Ryc.1. Porównanie znaków wybitych na toporze z Orłowa Murowanego z herbem rodziny Wippler. Oprac. J. Kuśnierz.

przypominające herb rodu Wipplerów umieszczone na toporze z Orłowa Murowanego (tabl. IV, C; tabl.vi, H). Herb przedstawia trzy krzyże połączone końcami. Jedna z gałęzi śląskiej rodziny Wipplerów wywodziła się z Uszyc koło Gorzowa Śląskiego, a druga z Gardawic w ziemi pszczyńskiej. W najbliższym otoczeniu Władysława Opolczyka znajdował się Piotr Wippler wspomniany w dokumentach w 1390 r. (Sperka 2006: 323, ryc. 24).

Możliwe również, że znak na toporze przedstawia nieco uproszczony herb Brodzic, kawalerskie krzyżyki [...] w rozstrój, stykajace się zaćwiczonymi skrajami, pierwszy raz wzmiankowany w źródłach pisanych w I4I4 r. Przedstawienie tego herbu znane jest z chrzcielnicy z przełomu XV i XVI w. w Jasionowie k. Brzozowa (Szymański 1993: 92). W trzech przypadkach na szyjach toporów spotyka się okrągłe znaki przypominające rozety (tabl.ıII, J; tabl.IV, H, I; tabl. viI, A, B, C).

Zabytek z Orłowa Murowanego (tabl. Iv, c) kojarzony z herbem Wippler ma górną powierzchnię obucha „kratkowaną”, co jest cechą, która według M. Głoska, dyskwalifikuje topór jako narzędzie ciesielskie służące m.in. do wbijania gwoździ (Głosek 1996: 30). Jednocześnie posiada asymetryczne ostrze wskazujące według badaczy na funkcję narzędzia ciesielskiego. Znaki kojarzone z herbem przemawiają jednak za tym, że mamy do czynienia z toporem bojowym. 
Wśród znaków kowalskich ujętych w kontur tarczy herbowej znajduje się jeszcze jeden ciekawy motyw. Na szyi topora z miejscowości Paary (położonej w obrębie dawnej Ordynacji Zamojskiej) wybito odwrócony wizerunek krzyża umieszczonego na kuli (tabl. IV, E i VI, F). Dostrzec tu można pewne nawiązanie do znaków wybitych na żeleźcu halabardy z Muzeum w Nysie i szyi topora typu XII z Domaszkowic, powiat nyski. Tu znaki krzyża ustawione są prawidłowo. Oba zabytki można datować na XV w. (Marek 2008: ryc. I59).

Sześć toporów z opisywanej kolekcji posiada na żeleźcach wybite otwory w kształcie liści koniczyny, zaś I 4 egzemplarzy nosi ornament, w kilku przypadkach bardzo rozbudowany. Wśród różnych wątków ornamentu wybitych na żeleźcach spotyka się pasmo znaków „x” (tabl. I, B), grupy wybitych punktów - w jednym przypadku tworzących koncentryczny okrąg (tabl.v, B; tabl.viı, K). Na żeleźcu innego topora wybite krótkie, klinowate wgłębienia układają się w gwiazdę (tabl.v, A). Regionalną cechą wydaje się umieszczanie w górnych narożnikach ściętych bród znaków składających się z wybitych "gwiaździstym” stemplem punktów uzupełnionych półksiężycami, co nadaje znakom wygląd komety (tabl. I, C; tabl. III, F, G, H; tabl. IV, C; tabl.viI, E, F, G, H). Ponadto trzy topory mają na górnych powierzchniach obuchów wybite linie układające się w jodełkę (tabl. III, J; tabl. IV, B) lub skośną kratkę (tabl. IV, C). Jeszcze jednym charakterystycznym wątkiem zdobniczym są rzędy punktów wybitych wzdłuż tylnych krawędzi szyjek biegnących ku narożnikom ściętych bród żeleźców (tabl.ıII, E, G, H; tabl.vI, C; tabl.viI, G, H). W przypadku jednego egzemplarza wzdłuż tylnej, prostej krawędzi żeleźca wybito osiem punktów ułożonych w linię (tabl. II, I; tabl. vII, I). Warto zwrócić uwagę na ciekawy egzemplarz z oryginalną, cofniętą osadą (tabl. II, H). Zdobiony jest grupą punktów, z których kilka połączono wybitymi liniami, uzyskując przedstawienie gałązki z jednej strony żeleźca (tabl. viI, L). Druga strona jest znacznie zniszczona - widać jedynie poziomo układającą się linię czterech punktów i słabo widoczne żłobki tworzące trójkąty. Okaz ten (tabl.II, H) pochodzi z okolic wsi Ulów leżącej u podnóża najwyższego wzniesienia polskiej części Roztocza (Wapielnia, 386 m n.p.m.), z dala od cieków wodnych, w okolicy mocno zalesionej. Wiązać go należy z wyrębami lasów i trudno datować bez znajomości warunków znalezienia i ewentualnych przedmiotów towarzyszących. Najbliższą analogię do tego topora, zarówno pod względem ogólnego kształtu, jak i ornamentu, stanowi egzemplarz z Mościsk k. Lwowa (Ławrynowicz, Strzyż 2003: 263, ryc. 2: 7).

Spośród omówionej serii toporów szczególnie wyróżnia się kilka egzemplarzy reprezentujących typ viIIa. Aż cztery z nich posiadają ornament niemal jednakowy pod względem stylistyki - znaki kowalskie ujęte w tarcze herbowe oraz rzędy punktów zakończonych przedstawieniami „komet” (tabl.III, F, G, H). Bogactwo ornamentu nasuwa skojarzenie $\mathrm{z}$ toporem tego samego typu znalezionym 


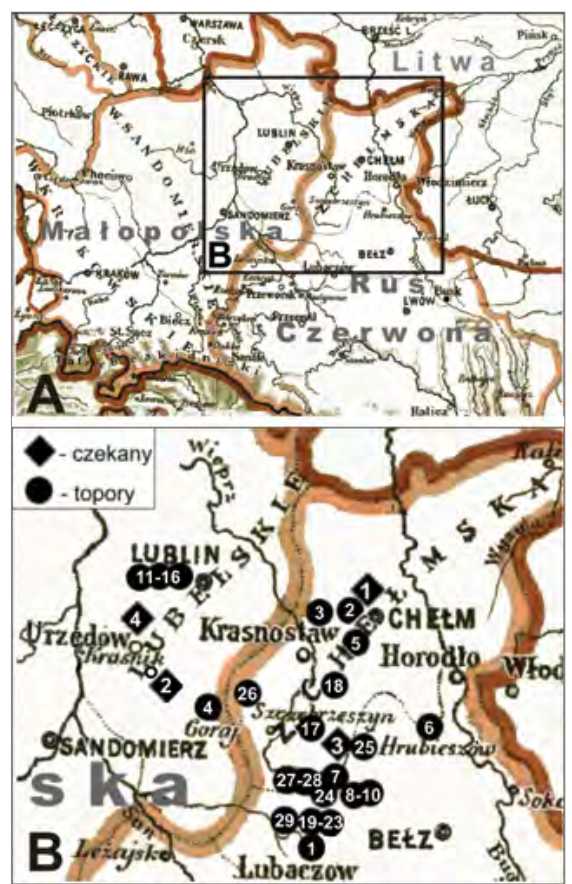

Ryc.2. A - pogranicze Małopolski i Rusi Czerwonej w XIV-XV w. B - lokalizacja znalezisk późnośredniowiecznych czekanów, toporów i siekier (numeracja zgodna z numerami katalogu).

Opracowano na podkładzie fragmentu mapy J. Babireckiego „Polska wieku xv”, https://rcin.org.pl/dlibra/publication/44II7/edition/27720/content [I II 2O2I].

w Łucku na Wołyniu, który autorzy opracowania starają się wiązać ze zjazdem monarchów odbytym w tym mieście w I 429 r. (Birulina, Kuśnierz 2007). Zjazd zorganizowany przez króla Władysława Jagiełłę przez i3 tygodni obradował nad problemem obrony Europy przed agresją Imperium Osmańskiego (Łowmiański r999: 68). Zbrojne orszaki europejskich monarchów zdążających do Łucka szlakami wiodącymi od Warszawy przez Lublin, Krasnystaw, czy od Sandomierza i Zawichostu wzdłuż północnych stoków Roztocza ku Włodzimierzowi Wołyńskiemu (m.in. Eryk Pomorski - król Danii, Szwecji i Norwegii oraz Zygmunt Luksemburski - król niemiecki, czeski i węgierski) mogły pozostawić pojedyncze okazy żeleźców toporów. To ponownie kieruje naszą uwagę na polityczne problemy pogranicza polsko-litewsko-ruskiego i jednocześnie uzasadnia sposób podejścia do tematu zastosowany w niniejszym artykule. Topory typu viIIa popularne były również w XVII w., o czym świadczą materiały pozyskane podczas prac wykopaliskowych I. Swiesznikowa na polu bitwy pod Beresteczkiem (I65I r.). Autor tych badań topory, kwalifikowane przez nas do typu viııa według klasyfikacji M.Głoska, zalicza do uzbrojenia chłopskich powstańców z armii Bohdana Chmielnickiego (Svyeshnykov 1993: 218; ryc. 50: 3,4; ryc. 51: I-4; 52: 3-7). Nadal więc pozostajemy na interesującym nas terenie, który w XVII w. był miejscem walk wojsk koronnych ze zbuntowanymi Kozakami i chłopską „czernią”, używającą w walkach używanych w gospodarstwach siekier, kos czy naprędce, prymitywnie wykonanych w wiejskich kuźniach włóczni.

Reasumując, należy stwierdzić, że opisana kolekcja czekanów, toporów i siekier z muzeów południowej Lubelszczyzny stanowi liczny, różnorodny i imponujący zbiór. Zawdzięczamy go głównie nielegalnym poszukiwaniom prowadzonym przez miłośników militariów. Szczególne nasilenie ich działań występuje w lasach 
Roztocza i nakierowane jest na poszukiwanie broni i oporządzenia wojskowego z obu wojen światowych. Zabytki archeologiczne znajdowane są niejako przy okazji. Gdyby wspomniani łowcy skarbów dostarczali do muzeów komplet znalezisk, to można przypuszczać, że m.in. zyskalibyśmy potwierdzenie, że omówione wyżej znaleziska z Osuch st. I3 (Łąka Byki) rzeczywiście zalegały na bagnistej przeprawie przez rzekę. W innych znanych archeologii przypadkach militariom wydobytym z okolic przepraw przez rzeki towarzyszyły podkowy końskie, radlice, strzemiona, wędzidła, sierp, okucie łopaty (Radymno), czy, jak w Nowym Korczynie, rękojeść miecza, podkowy, ciosła, pierścionek, nożyki, okucia (Kajzer, Rychter 1997: I45, I48). Rozległe lasy Roztocza zapewniają łowcom skarbów znaczny stopień anonimowości. Zdarza się jednak, że niektórzy poszukiwacze zdają sobie sprawę ze szkód, jakie wyrządzają kontekstowi archeologicznemu, wyrywając zeń pośpiesznie znalezione artefakty. Rekompensują to, przekazując je do muzeów. Niemniej jednak te szczątkowe dane, jakie możemy uzyskać od znalazców, w znaczący sposób poszerzają bazę naukową, a przybliżona lokalizacja w terenie pozwala sporządzać mapy pomagające potwierdzić przebieg średniowiecznych szlaków handlowych i wojennych. Ważne jest to szczególnie dla obszaru obecnego województwa lubelskiego, które administracyjnie łączy północno-zachodnią część historycznej Rusi Czerwonej i północno-wschodnie tereny Małopolski położone na prawym brzegu środkowej Wisły.

\section{Katalog 3}

(podział typologiczny, nomenklatura i miejsca pomiarów wg M. Głosek 1996)

\section{Czekany}

1. Chełm, pow. loco, woj. lubelskie. (Tabl. I, A). Czekan żelazny znaleziony w studni w trakcie badań archeologicznych; Chron.: Xv-XviII w. Typ If. Wymiary: dl. ogólna - I9,5 cm; szer. ostrza - 8,4 cm; najmn. szer. szyjki - 3,2 cm; dł. osady $-6,7 \mathrm{~cm}$; dt. młotka - 4,5 cm; częściowo zachowany fragment drewnianego toporzyska dt. ok. $25 \mathrm{~cm}$. Lit.: Bronicki i in. 1991: I28, ryc. 13 b.

2. Kraśnik, pow. loco, woj. lubelskie. (Tabl. I, B). Nieznane okoliczności znalezienia. Czekan żelazny o długiej, ściętej brodzie i łukowatym ostrzu. Muzeum Lubelskie, nr inw. 734/A/ML. Chronologia: I. poł. XV w. Typ Ie. Wymiary:

3 Składam szczególne podziękowania Panu Doktorowi Piotrowi Kotowiczowi, który oddał mi do dyspozycji sporządzone przez siebie znakomite rysunki i opisy całej kolekcji toporów znajdujących się w zbiorach Muzeum Regionalnego im. dr Janusza Petera w Tomaszowie Lubelskim. 
dł. ogólna - I4,o cm; szer. ostrza - Io cm; najmn. szer. szyi - 2,2 cm; szer. osady - 3,4 cm; światło osady - 4,0 x 2,3 cm. Egzemplarz bogato zdobiony: na żeleźcu wybite pięć znaków „x” (rzymskich dziesiątek?), na szyi, osadzie i młotku rzędy skośnych kratek ujętych poziomymi liniami tworzącymi poziome pasma. Lit.: Kuśnierz 2oı ob: rys. 4: I.

3. Swaryczów, gm. Komarów-Osada, pow. zamojski, woj. lubelskie. (Tabl. I, D; tabl.vi, I; tabl.viI, J). Znalezisko luźne odkryte przy pomocy detektora metali. Muzeum Zamojskie w Zamościu, nr inw. Mz/300/A. Chronologia: XV w. Czekan żelazny typu Ig. Wymiary: dł. ogólna - 20,4 cm; szer. ostrza - 13,6 cm; najmniejsza szer. szyjki - 4,o cm; dł. osady - I2,6 cm; dł. młotka - 2,6 cm; waga - 882 g. Znaki i zdobienia: poniżej osady listwa ozdobna z metalu kolorowego, poniżej podwójny znak kowalski, na żeleźcu wybity znak „x” (krzyż św. Andrzeja) oraz otwór w kształcie liścia koniczyny. Lit.: Kuśnierz 20ıа: 22I-222, ryc. 9, kat. 5 na s.229.

4. Urzędów, gm. loco, pow. kraśnicki, woj. lubelskie. (Tabl. I, C). Czekan w zbiorach PMA Warszawa, nr inw. PMA vi/1304. Chronologia: XV w. Typ Ig. Wymiary: dł. ogólna - I6,2 cm; szer. ostrza - IO,I cm; najmn. szer. szyjki - 2,7 cm; dł. osady - 5,0 cm; średnica światła osady - 2,0 cm. Znaki i zdobienia: znak kowalski na szyjce, ornament na żeleźcu. Lit.: Głosek 1996: 30, nr kat. I2, Tabl.viII, A.

\section{Topory i siekiery}

1. Borowiec, st. 4, gm. Łukowa, pow. biłgorajski, woj. lubelskie. (Tabl.v, B; tabl.viı, K). Muzeum Tomaszów Lubelski, nr inw. MT/ı073/H. Chronologia: XV w. Typ XII. Wymiary: dl. ogólna - 20,8 cm; szer. ostrza - 29,I cm; najmn. szer. szyjki - 8,o cm; średnica światła osady - 3,6 x 3,0 cm, waga - 1580 g. Znaki i zdobienia: na żeleźcu wybite punkty układające się w okrąg i kilka słabo widocznych punktów na płaszczyźnie brody topora. Lit.: niepublikowany.

2. Chełm, pow. loco, woj. lubelskie. (Tabl. IV, A). Znaleziony w studni podczas badań archeologicznych; Chronologia: XV-XVIII w. Typ IXa. Wymiary: długość ogólna - 24,7 cm; szer. ostrza - I2,7 cm; najmn. szer. szyjki 5,3 cm; dl. osady - 5,8 cm; średn. osady - 3,5 cm. Lit.: Bronicki i in. I991: 132, ryc. I3a.

3. Czechów Kąt, gm. Rejowiec, pow. chełmski, woj. lubelskie. (Tabl. IV, D). Muzeum Regionalne w Krasnymstawie, nr inw. MK/A/3IO. Chronologia: XIV-XVI w. Typ IXa. Wymiary: dł. ogólna - 24,3 cm; szer. ostrza - I2,2 cm, najmn. szer. szyjki - 2,2 cm; dł. osady - 4,7; światło otworu - 5,0 x 3,0 cm; waga - I400 g. Lit.: niepublikowany.

4. Goraj, gm. loco, pow. biłgorajski, woj. lubelskie. (Tabl. II, A). Znalezisko przypadkowe w trakcie prac budowlanych na prywatnej posesji nieopodal kościoła. 
Muzeum Regionalne w Kraśniku. Chronologia: k. XIII-XV w. Typ vd. Wymiary: dł. ogólna I7,0 cm; szer. ostrza - I4,4 cm; najmn. szer. szyjki - 2,2 cm, średnica światła osady - 4,8 x 3,7 cm. Lit.: Wichrowski 2000: 2I2-2I4, ryc. I.

5. Horodysko, gm. Leśniowice, pow. chełmski, woj. lubelskie. (Tabl. III, D). Znaleziony podczas badań archeologicznych na grodzisku. Muzeum Lubelskie, nr inw. 992/A/r. Chronologia: XII-XIV w. Typ viIIa. Wymiary: długość ogólna $-6,9 \mathrm{~cm}$; szer. ostrza - ok. 4,o cm; najmn. szer. szyjki - ok. I, $8 \mathrm{~cm}$; światło osady - 2,2 X 2,0 cm. Lit.: Głosek 1996: 86, tabl. XV, B.

6. Hrubieszów, pow. loco, woj. lubelskie. (Tabl. IV, I; tabl.viI, A). Znalezisko luźne. Muzeum Hrubieszów, nr inw. MH/H/275. Chronologia: XIV-XV w. Typ x. Wymiary: dł. ogólna $-29,2 \mathrm{~cm}$; szer. ostrza $-26,8 \mathrm{~cm}$; d. osady $-26,0 \mathrm{~cm}$; najmn. szer. szyjki - 3,4 cm; waga - 655 g. Znaki i zdobienia: znak kowalski wykonany stemplem na szyjce. Lit.: Kuśnierz 2010b: ryc. 3: 7.

7. Kolonia Rogóźno, gm. Tomaszów Lubelski, pow. tomaszowski, woj. lubelskie. (Tabl. III, I). Znalezisko luźne. Muzeum Tomaszów Lubelski, nr inw. MT/I074/A. Chronologia: 2. poł. XIII-XVI w. Typ vinIa. Wymiary: dł. ogólna - I8,5 cm; zachowana szer. ostrza - ok. 8,o cm; dl. osady $-6,7 \mathrm{~cm}$; światło osady $-4,4$ X 3, I cm, waga -655 g. Lit.: niepublikowany.

8. Leliszka, gm. Jarczów, pow. tomaszowski, woj. lubelskie. (Tabl. II, C). Znalezisko luźne. Muzeum Tomaszów Lubelski, nr inw. MT/ııo/A. Chronologia: XII-XIV w. Typ viIa. Wymiary: dł. ogólna - 17,4 cm; szer. ostrza - I2,4 cm; dł. osady - 5,I cm; najmn. szer. szyjki - 3,6 cm; średn. światła osady - 3,8 x 3,4 cm; waga -860 g. Lit.: niepublikowany.

9. Leliszka, gm. Jarczów, pow. tomaszowski, woj. lubelskie. (Tabl. II, G).Znalezisko luźne. Muzeum Tomaszów Lubelski, nr inw. MT/I160/A. Chronologia: 2. poł. XIII-XV w. Typ viII. Wymiary: dł. ogólna - I5,2 cm; szer. ostrza $-8,5 \mathrm{~cm}$; dt. osady $-7, \mathrm{I} \mathrm{cm}$; najmn. szer. szyjki $-3,8 \mathrm{~cm}$; światło otworu osady $-3,5 \times 3,3 \mathrm{~cm}$; waga -639 g. Lit.: niepublikowany.

10. Leliszka, gm. Jarczów, pow. tomaszowski, woj. lubelskie. (Tabl. v, A; tabl.vi, A). Znalezisko luźne. Muzeum Tomaszów Lubelski Nr MT/ıı2o/A. Chronologia: XV w. Typ XII. Wymiary: dl. ogólna -23,I cm; szer. ostrza $-25,2 \mathrm{~cm}$; dt. osady - I4,0 cm; najmn. szer. szyjki $-5,9 \mathrm{~cm}$; światło otworu osady - ok. 3,3 x ok. 2,0 cm; waga - 95 r g. Znaki i zdobienie: na szyi dwa znaki kowalskie, na żeleźcu słabo zachowany ornament w postaci wybitej przecinakiem gwiazdy oraz rozrzuconych punktów. Lit.: niepublikowany.

11. Lublin. (Tabl. II, в). Topór znaleziony podczas badań archeologicznych przy klasztorze dominikanów, zbiory d. PP PKZ w Lublinie. Chronologia: XV w. Typ VII; wymiary: dł. ogólna -I9,4 cm; szer. ostrza - I7,5; najm. szer. szyjki - 3,3; dług. osady - 4,9; światło osady - 2,1 x 4,5. Lit.: Głosek 1996: 87, nr kat. 47, tabl. XII, B. 
12. Lublin, podnóże Zamku. (Tabl.ıII, F; tabl.vi, G; tabl.viı, E). Muzeum Lubelskie, nr inw. I883/ML/A. Chronologia: 2. poł. XIII-XVI w. Typ viIIa. Wymiary: dł. ogólna - 3I,3 cm; szer. ostrza - 9,8 cm; najmn. szer. szyjki - 3,8 cm; dł. osady $-8,2 \mathrm{~cm}$; światło osady $-4,7$ x 2,8 cm. Znaki i zdobienia: na szyi trzy znaki kowalskie, w narożniku brody wybity ornament w kształcie gwiaździstego bodźca ostrogi (komety?). Wszystkie znaki wypełnione kolorowym metalem. Lit.: Kuśnierz 2orob: ryc. 2: 8.

13. Lublin, podnóże Zamku. (Tabl. III, J; tabl. viı, B). Muzeum Lubelskie, nr inw. I88I/ML/A. Chronologia: 2. poł. XIII-XVI w. Typ IX. Wymiary: dł. ogólna - I8,8 cm; szer. ostrza - I3,0 cm; najmn. szer. szyi - 2,9 cm; dł. osady - 5,2 cm; światło otworu osady - 5,0 x 2,7 cm. Znaki i zdobienia: znak kowalski na szyi, obuch z ornamentem jodełki zamkniętej w prostokątnej ramce, w żeleźcu otwór w kształcie kropli. Lit.: Kuśnierz 2oıob: ryc. 2: ıо.

14. Lublin, podnóże Zamku. (Tabl. IV, B; tabl. viI, D). Muzeum Lubelskie, nr inw. I882/ML/A. Chronologia: XIV-XVI w. Typ IXa. Wymiary: dł. ogólna - 21,5 cm; szer. ostrza - I3,7 cm; najmn. szer. szyjki - 3,7 cm; dl. osady $-6,8 \mathrm{~cm}$; światło otworu osady - 4,0 x 2,5 cm. Znaki i zdobienia: na przejściu szyi w żeleźce otwór w kształcie liścia koniczyny, otwór ograniczony trzema punktami połączonymi liniami tworzącymi kąt skierowany ku górze. Obuch zdobiony ornamentem jodełki zamkniętej w prostokątnej ramce. Lit.: Kuśnierz 2oı b: ryc. 3: 2.

15. Lublin, podnóże Zamku. (Tabl. IV, F; tabl.vi, B). Muzeum Lubelskie, nr inw. 1890/ML/A. Chronologia: XIV-XV w. Typ x. Wymiary: dł. ogólna - 40,o cm; szer. ostrza - 32,5 cm; najmn. szer. szyi $-3,6 \mathrm{~cm}$; dł. osady $-38,0 \mathrm{~cm}$; światło otworu - 3,0 x I,2 cm. Znaki i zdobienia: znak kowalski na szyi. Lit.: Kuśnierz 2oiob: ryc. 3: 8 .

16. Lublin, podnóże Zamku. (Tabl. IV, H; tabl. viı, C). Muzeum Lubelskie, nr inw. I89I/ML/A. Chronologia: XIV-XV w. Typ X. Wymiary: dł. ogólna $-37,5 \mathrm{~cm}$; szer. ostrza - 35,0 cm; najmn. szer. szyi - 5,5 cm; dł. osady - 34,5; światło otworu osady - 3,0 x I,5 cm. Znaki i zdobienia: znak kowalski na szyi. Lit.: Kuśnierz 2orob: ryc. 3: 9 .

17. Łabunie, gm. loco, pow. zamojski, woj. lubelskie. (Tabl. III, E; tabl. vi, c). Znalezisko przypadkowe podczas robót ziemnych. W kolekcji prywatnej znalazcy. Chronologia: XIV-XVI w. Topór żelazny typu viIIa. Dł. całkowita - I6,8 cm; szer. ostrza - 7,65 cm; szerokość podciętej brody $-6,0 \mathrm{~cm}$; dl. osady $-5,8 \mathrm{~cm}$; światło osady - 4,3 x 3,I cm. Znaki i zdobienia: znak kowalski na szyi i zdobienie rzędem nabitych punktów wzdłuż tylnej krawędzi żeleźca. Lit. Kuśnierz 2010a: 222-223, ryc. II.

18. Orłów Murowany, gm. Izbica, pow. krasnostawski, woj. lubelskie. (Tabl. IV, C; tabl.vi, H; tabl.viı, F). Topór znaleziony na łące w dolinie rzeki Wolica, w pobliżu ruin zamku. Muzeum Zamojskie nr inw. Mz/338/A. Chronologia: 
XIV-XVI w. Typ IXa. Wymiary: dł. ogólna - I8,2 cm; szer. ostrza - II,o cm; dł. osady - 4,7 cm; światło osady - 3,8 x 2,6 cm; waga $472 \mathrm{~g}$. Znaki i zdobienia: na szyi dwa znaki kowalskie, w narożniku ściętej brody znak gwiazdki ze skośnym „ogonem” (kometa?), obuch z ornamentem skośnej kratki i jednym wybitym punktem, na żeleźcu wybity otwór w kształcie liścia koniczyny. Lit.: niepublikowany.

19. Osuchy st. I3, gm. Łukowa, pow. biłgorajski, woj. lubelskie. (Tabl. II, D). Znalezisko luźne. Muzeum Tomaszów Lubelski, nr inw. MT/ı130/ı/A. Chronologia: 2. poł. XIII-XV w. Typ viII. Wymiary: dł. ogólna - I8,9 cm; szer. ostrza - 8,2 cm; dł. osady - ok. 6,7 cm; najmn. szer. szyjki - 4,I cm; światło otworu osady - 3,2 x 2,9 cm; waga - 640 g. Znaki i ornament: zniszczony znak kowalski na szyjce (na stronie niewidocznej na rys.). Lit.: niepublikowany. 20. Osuchy stan. I3; gm. Łukowa, pow. biłgorajski, woj. lubelskie. (Tabl. II, E). Znalezisko luźne. Muzeum Tomaszów Lubelski, nr inw. MT/ı 49/ı/A. Chronologia: 2. poł. XIII-XV w. Typ viII. Wymiary: dł. ogólna - I7,I cm; szer. ostrza - 8,6 cm; dł. osady - 5, I cm; najmn. szer. szyjki - 3,8 cm; światło otworu osady - 3,9 x 3,0 cm; waga - 594 g. Lit.: niepublikowany.

21. Osuchy stan. I3; gm. Łukowa, pow. biłgorajski, woj. lubelskie. (Tabl. III, A). Znalezisko luźne. Muzeum Tomaszów Lubelski, nr inw. MT/ıi 49/2/A. Chronologia: 2. poł. XIII-XV w. Typ VIII. Wymiary: dł. ogólna - 20,0 cm; szer. ostrza - 5,2 cm; dł. osady - 7,6 cm; najmn. szer. szyjki - 3,5 cm; światło otworu osady $-3,6$ x 3,2 cm; waga -806 g. Lit.: niepublikowany.

22. Osuchy stan. I3, gm. Łukowa, pow. biłgorajski, woj. lubelskie. (Tabl. III, G; tabl.vi, J; tabl.viı, H). Znalezisko luźne. Muzeum Tomaszów Lubelski, nr inw. MT/ı053/A. Chronologia: 2. poł. XIV-XVI w. Typ viıIa. Wymiary: dł. ogólna $-20,2 \mathrm{~cm}$; szer. ostrza $-9,3 \mathrm{~cm}$; dł. osady $-7,0 \mathrm{~cm}$; najmn. szer. szyjki - 4, I cm; światło otworu osady - 4,4 x 2,8 cm; waga - 1354 g. Znaki i ornament: znak kowalski na szyjce i cztery punkty wybite puncą o krawędzi „gwiaździstej”, rozmieszczone wzdłuż górnej krawędzi brody żeleźca. Dolny punkt uzupełniony wybitym półksiężycem, co tworzy „kometę”. Lit.: niepublikowany.

23. Osuchy st. I3, gm. Łukowa, pow. biłgorajski, woj. lubelskie. (Tabl. III, K). Znalezisko luźne. Muzeum Tomaszów Lubelski, nr inw. MT/1130/2/A. Chronologia: 2. poł. XIV-XVI w. Typ IX. Wymiary: dł. ogólna - I5,2 cm; zachowana szer. ostrza $-7,9 \mathrm{~cm}$; dł. osady $-3,8 \mathrm{~cm}$; najmn. szer. szyjki $-2,2 \mathrm{~cm}$; światło osady $-3,8$ x 2,8 cm, waga $-348 \mathrm{~g}$. Uwaga: w osadzie zachowany fragment drewnianego toporzyska, w którym tkwią trzy kliny żelazne o płaskich główkach. Lit.: niepublikowany.

24. Paary, gm. Susiec, pow. Tomaszowski, woj. lubelskie. (Tabl. IV, E; tabl. vi, F). Znalezisko luźne. Muzeum Tomaszów Lubelski, nr inw. MT/I072/A. Chronologia: 
XIV-XVI w. Typ IXa. Wymiary: dł. ogólna - I9,0 cm; szer. ostrza - I6,7 cm; dł. osady $-6,8 \mathrm{~cm}$; najmn. szer. szyjki $-5, \mathrm{I} \mathrm{cm}$; światło otworu osady - 3,8 x 3,2 cm; waga - 627 g. Znaki i zdobienia: znak kowalski na szyi. Lit.: niepublikowany.

25. Perespa, gm. Tyszowce, pow. tomaszowski, woj. lubelskie. (Tabl. IV, G; tabl. vi, E). Znalezisko luźne. Muzeum Tomaszów Lubelski, nr inw. MT/II22/2/A. Chronologia: XIV-XVI w. Typ IXa. Wymiary: dł. ogólna - II,I cm; zachowana szer. ostrza - 9,5 cm; dł. osady - 3,6 cm; najmn. szer. szyjki $-2,9 \mathrm{~cm}$; światło otworu - 2,6 x I,7 cm; waga - I82 g; znaki i zdobienia: znak kowalski na szyjce. Lit.: niepublikowany.

26. Sąsiadka, gm. Sułów, pow. zamojski, woj. lubelskie. (Tabl. III, L). Znalezisko luźne (z grodziska?). Muzeum Lublin. Chronologia: XIV-? w. Typ IXa. Wymiary: długość ogólna - ok. I8,o cm; szer. ostrza - ok. I1,o cm. Lit.: Głosek 1996: 91, tabl. XxiII, B.

27. Ulów, gm. Tomaszów Lubelski, pow. Tomaszowski, woj. lubelskie. (Tabl. II, H; tabl. viI, L). Muzeum Tomaszów Lubelski, nr inw. MT/ı050/A. Chronologia: 2. poł. XIII-XV w. Typ VIII. Wymiary: dł. ogólna - I4,I cm; szer. ostrza - 7,2 cm; dł. osady - 4,5; najmn. szer. szyjki - 4,2 cm; światło otworu - 3,5 x 3,1 cm; waga -636 g. Znaki i zdobienia: na żeleźcu obustronny ornament w postaci punktów połączonych liniami. Lit.: niepublikowany.

28. Ulów, gm. Tomaszów Lubelski, pow. Tomaszowski, woj. lubelskie. (Tabl. III, B). Znalezisko luźne. Muzeum Tomaszów Lubelski, nr inw. MT/1070/2/A. Chronologia: 2. poł. XIII-XV w. Typ VIII. Wymiary: dł. ogólna $-6,3 \mathrm{~cm}$; szer. ostrza - 2,9 cm; dl. osady - 2,I cm; najmn. szer. szyjki - I, $4 \mathrm{~cm}$; światło otworu osady - I,7 x 2,0, waga - 399 g. Lit.: niepublikowany.

29.Zanie, gm. Księżpol, pow. biłgorajski, woj. lubelskie. (Tabl. III, H; tabl. vi, D; tabl. viI, G). Muzeum Biłgoraj. Chronologia: XIV-Xvi w. Typ viıIa. Wymiary: dł. ogólna - 2I,7 cm; szer. ostrza - I0,5 cm; dł. osady - 7,4 cm; najmn. szer. szyi - 6,I cm; światło otworu - 4,9 x 3,4 cm; waga - I3II g. Znaki i zdobienia: na szyi dwa znaki kowalskie, pod nimi punkt wybity stemplem z "gwiaździstą" krawędzią. Wzdłuż tylnej krawędzi szyi i narożnika ściętej brody rząd sześciu identycznych punktów, z których ostatni dolny styka się z półksiężycowatym rowkiem dając efekt „komety”. Lit. niepublikowany.

30.m. n. „Puszcza Solska” (brak lokalizacji). (Tabl.ıII, C). Zbiory prywatne A. Kitki w Lublinie. Chronologia: 2. poł. XIII-Xv w. Typ viII. Wymiary: dł. ogólna - 8,o cm; szer. ostrza - 3,I cm; dł. osady - 2,4 cm; światło otworu - 2,2 X 1,5 cm. Lit.: Ławrynowicz, Strzyż 2001: 262, ryc. 2: 6.

31. m. nieznana, pow. Biłgoraj. Muzeum Biłgoraj. (Tabl. II, I; tabl. viI, I). Chronologia: XIV-XV w. Typ VIII. Wymiary: dt. ogólna - I8,4 cm; szer. ostrza - 7,3 cm; dł. osady - 7,4 cm; najmn. szer. szyi - 4,8 cm; światło otworu - 4,3 x 3,2 cm; 
waga - 755 g. Znaki i zdobienia: wzdłuż tylnej krawędzi żeleźca osiem punktów wybitych stemplem. Lit.: niepublikowana.

32. m. nieznana, dawne woj. zamojskie. (Tabl. II, F). Znalezisko luźne. Muzeum Zamojskie w Zamościu, nr inw. / MZ/448/RA. Chronologia: 2. poł. XIII-XVI w. Typ IX. Wymiary: dł. ogólna - 20,7 cm; szer. ostrza - II,8 cm; dł. osady - 4,7 cm; najmn. szer. szyi - 3,I cm; światło osady - 4,3 x 2,6; waga - 948 g. Lit.: niepublikowany.

\section{Bibliografia}

\section{Źródła}

Jan Długosz, Roczniki czyli kroniki stawnego Królestwa Polskiego. Ksiegra dziesiąta i księga jedenasta. $1406-1412$, Warszawa 1982.

\section{Opracowania}

Baczkowski K. (1999), Dzieje Polski późnośredniowiecznej (1370-I506), Fogra, Kraków (Wielka Historia Polski, 3).

Birulina E., Kuśnierz J. (2007), Ornamentowana siekiera ze zbiorów Wotyńskiego Muzeum Krajoznawczego w Eucku, „Acta Militaria Mediaevalia”, 3, s. 209-215.

Bronicki A., Kadrow S., Tokarski L. (199I), Staromiejska studnia na rynku w Chetmie, „Kwartalnik Historii Kultury Materialnej”, 39.2, s. 117-137.

Głosek M.(1996), Późnośredniowieczna broń obuchowa w zbiorach polskich, Instytut Archeologii i Etnologii Polskiej Akademii Nauk, Warszawa-Łódź.

Janeczek A. (1993), Osadnictwo pogranicza polsko-ruskiego. Województwo betskie od schytku XIV do poczattku XVII w., Wydawnictwo Instytutu Archeologii i Etnologii Polskiej Akademii Nauk, Warszawa.

Kajzer L., Rychter M. (1997), Zespót średniowiecznych militariów z Nowego Korczyna, „Kwartalnik Historii Kultury Materialnej”, 45.2, s. I45-160.

Kirpichnikov A.N. (1966), Drevnerusskoye oruzhiye 2. Kop'ya, sulitsy, boyevyye topory, bulavy, kisteni IX-XIII v.v., Arkheologiya SSSR. SAI, Moskva-Leningrad (Кирпичников А.Н. (1966), Аревнерусское оружие 2. Копья, сулищь, боевые топорьи, булавы, кистени ІХ-ХІІІ в.в., Археология СССР. САИ, Москва-ИенинграА).

Kloss A.(b.d.), Późnośredniowieczne topory, siekiery i czekan w zbiorach Działu Archeologii Muzeum Lubelskiego (maszynopis niedatowany w archiwum Działu Archeologii Muzeum Narodowego w Lublinie).

Kotowicz P.N. (2014), Topory wczesnośredniowieczne z ziem polskich. Katalog źródet, Rzeszów.

Kuśnierz J. (2010a), Wybrane militaria późnośredniowieczne w zbiorach muzeów i kolekcjach prywatnych potudniowej Lubelszczyzny, "Acta Militaria Mediaevalia”, 6, s.2I-232.

Kuśnierz J. / Kusnež E. (2oIob), Nahodki mečej i toporov s XIV-XV vv. vpograničnoj zone Črvonoj Rusi i Pol'skogo korolestva na fone vooružënnyh konfliktov Vengrii, Pol’si 
i Litvy za Rus'i vojny z Tevtonskim ordenom v I4Io g., [w:] Russkoe nasledie v stranah Vostočnoj i Central'noj Evropy, Brânsk, s.327-34I (Куснеж E. (2010b), Находки мечей и топоров с XIV-XV вв. в пограничной зоне Червоной Руси и Польского королества на фоне вооружённысх конфликтов Венгрии, Польши и Аитвы за Русь и войны з Тевтонским орденом в г4іо г., [w:] Русское наследие в странах Восточной и Центральной Европьь, Брянск, s.327-34I).

Łaszkiewicz T., Michalak A. (2007), Broń i oporządzenie jeździeckie z badań i nadzorów archeologicznych na terenie Międzyrzecza, „Acta Militaria Mediaevalia”, 3, s. 99-176.

Ławrynowicz O., Strzyż P. (2003), Nowe zabytki broni obuchowej z okolic Roztocza, „Archeologia Polski Środkowowschodniej”, 6 (za 200I r.), s. 258-264.

Łowmiański H. (1999), Polityka Jagiellonów, Wydawnictwo Poznańskie, Poznań 1999.

Maciukiewicz-Czarnecka B. (1992), Katalog militariów Polski pótnocno-wschodniej. Czesśc IV. Topory, „Zeszyt Naukowy Muzeum Wojska”, 6, s. 106-120.

Manteuffel T., Dowiat J. (1980), Monarchia wczesnopiastowska, [w:] J. Tazbir (red.), Zarys historii Polski, Państwowy Instytut Wydawniczy, Warszawa, s.9-100.

Marek L. (2004), Przyczynek do poznania broni biatej wroctawskiej piechoty $z$ XIV-XVI wieku, [w:] J. Piekalski, K. Wachowski (red.), Wroctaw na przetomie średniowiecza i czasów nowożytnych. Materialne przejawy życia codziennego, Uniwersytet Wrocławski, Wrocław (Wratislavia Antiqua, 6), s. 42-56.

Marek L. (2008), Broń biata na Ślasku. XIV-XVI wiek, Instytut Archeologii Uniwersytetu Wrocławskiego, Wrocław (Wratislavia Antiqua, Io).

Samsonowicz H. (1973), Przemiany sieci drożnej w Polsce późnego średniowiecza, „Przegląd Historyczny", 64.6, s. 697-716.

Shnicar M. (2019), A Late Medieval Hammer Axe from L'viv, „Acta Militaria Mediaevalia”, I5, S. 159-164.

Sperka J. (2006), Otoczenie Wtadystawa Opolczyka w latach 1370-I40I, Wydawnictwo Uniwersytetu Śląskiego, Katowice.

Svyeshnykov I.K., Bytva pid Berestechkom, L’viv 1993 (Свєшников I.К. (1993), Битва nid Берестечком,

Szczygieł R. (1994), Lokacja Florianowa na tle urbanizacji środkowego i wschodniego Roztocza w XVI i pierwszej potowie XVII wieku, „Rocznik Lubaczowski”, 5, I994, s. 5-16.

Szczygieł R. (2006), Lokacja miasta na prawie niemieckim i jego dzieje do końca XV wieku, [w:] R. Szczygieł (red.), Dzieje Hrubieszowa, t. I, Odpradziejów do IgI8 r., Urząd Miejski, Hrubieszów, s. 87-102.

Szczygieł R. (2017), Lokacja Lublina na prawie brandenburskim i jego dzieje w XIV i XV wieku, [w:] G. Figiel, R. Szczygieł, W.Śladkowski (red.), Lublin. 700 lat dziejów miasta, Wojewódzka Biblioteka Publiczna im. Hieronima Łopacińskiego, Lublin, s. 37-6o.

Szymański J. (1993), Herbarz średniowiecznego rycerstwa polskiego, Państwowe Wydawnictwo Naukowe, Warszawa.

Szymczak J. (2016), Zbrojna eskorta miejskich wozów wojennych w Polsce w XV-XVI w., "Studia z Dziejów Średniowiecza”, 20, s.283-305.

Świątkiewicz P. (2010), Militaria ze średniowiecznego grodziska w Raciażu, „Acta Militaria Mediaevalia", 6, s. 7-92. 
Świeżawski A. (1990), Ziemia betska. Zarys dziejów politycznych do roku I462, Wydawnictwo Wyższej Szkoły Pedagogicznej, Częstochowa.

Świeżawski A. (2007), Regencja Wtadystawa Opolczyka na Rusi Czerwonej, [w:] M. Antoniewicz, J.Zbudniewicz (red.), Ksiażze Wtadystaw Opolczyk. Fundator klasztoru Paulinów na Jasnej Górze w Częstochowie, Wydawnictwo Dig, Warszawa, s. 247-290.

Tkaczyk J. (2016), Szlaki komunikacyjne i handlowe wokresie średniowiecza i nowożytności na obszarze wspótczesnej Lubelszczyzny, [w:] Drogi Lubelszczyzny. Odkrycia i badania archeologiczne, Wojewódzki Urząd Ochrony Zabytków, Lublin, s. 25-42.

Trawkowski S. (1980), Schytek wieków średnich, [w:] J. Tazbir (red.), Zarys historii Polski, Państwowy Instytut Wydawniczy, Warszawa, s. 103-166.

Voytovych L. (2011), Pol's'kyy korol' Kazymyr i borot'ba za spadshchynu romanovychiv, L'viv (Visnyk L'vivs'koho universytetu. Seriya istorychna, 46), s. 17-4I (Войтович $\Lambda$. (2оі), Польський король Казимир і боротьба за спадщину Романовичів, Аьвів (Вісник $\Lambda$ ьвівського університету. Серія історична, 46), s. 17-4I).

Wichrowski Z. (2000), Średniowieczny topór z Goraja, pow. Bitgoraj, woj. Lubelskie, "Archeologia Polski Środkowowschodniej”, 5, s. 212-214.

Wyrozumski J.(1999), Dzieje Polski piastowskiej (VIII wiek - 1370), Fogra, Kraków (Wielka Historia Polski, 2).

Zahajkiewicz M.T. (1985), Diecezja Lubelska. Informator historyczny i administracyjny, Wydawnictwo Kurii Biskupiej, Lublin.

\section{Summary}

In the Middle Ages, the area of the present-day Lublin region, neighbouring with the Ukraine and Belarus, constituted borderlands between the historical Lesser Poland and Red Ruthenia, for which the then rulers of Poland, Hungary and Lithuania competed. Complicated family and dynastic relations were the cause of disputes and wars. The rulers, referring to blood ties and inheritance rights, made claims to the territory of Red Ruthenia. Military expeditions were organized, more important castles were besieged, and alliances were made. The political plotting and conflicts concerned the heirs of the Ruthenian rulers of the Romanowicz family: the Hungarian Arpads and Anjou, the Polish Piasts and the Grand Dukes of Lithuania. After the final annexation of Ruthenia to the Polish Crown by Queen Jadwiga in 1387 , intensive colonization and romanization of these lands began. All these events contributed to the fact that a significant number of military finds are nowadays obtained in this area, including pickaxes and battle axes. They are found along former communication and trade routes, river crossings, and in areas affected by armed conflicts. These artefacts represent many types distinguished by the experts in arms. Numerous copies have blacksmith's marks and decorations stamped. The pickaxes and battle axes described above are kept in the collections of museums in Lublin, Zamość, Hrubieszów, Krasnystaw, Kraśnik and Tomaszów Lubelski.

Keywords: Lesser Poland, Red Ruthenia, Hungary, Lithuania, Piasts, Arpads, Anjou, pickaxes and battle axes, the Middle Ages 
Anna Kloss (1940-2004)

Mgr archeologii (UMCS w Lublinie)

Pracownik (od 1965) i kierownik Działu Archeologii Muzeum Lubelskiego (1970-1996)

\section{Jerzy Kuśnierz}

Muzeum Zamojskie w Zamościu

e-mail: archeo@muzeum-zamojskie.pl 